University of New Hampshire

University of New Hampshire Scholars' Repository

$4-27-2008$

\title{
The impact of local sources and long-range transport on aerosol properties over the northeast U.S. region during INTEX-NA
}

\author{
$\mathrm{K} \mathrm{L}$. Thornhill \\ NASA \\ Gao Chen \\ NASA \\ Jack E. Dibb \\ University of New Hampshire, jack.dibb@unh.edu \\ C. Jordan \\ University of New Hampshire \\ Ali Omar \\ NASA
}

See next page for additional authors

Follow this and additional works at: https://scholars.unh.edu/earthsci_facpub

Part of the Atmospheric Sciences Commons

\section{Recommended Citation}

Thornhill, K. L., et al. (2008), The impact of local sources and long-range transport on aerosol properties over the northeast U.S. region during INTEX-NA, J. Geophys. Res., 113, D08201, doi:10.1029/

2007JD008666.

This Article is brought to you for free and open access by the Earth Sciences at University of New Hampshire Scholars' Repository. It has been accepted for inclusion in Earth Sciences Scholarship by an authorized administrator of University of New Hampshire Scholars' Repository. For more information, please contact Scholarly.Communication@unh.edu. 


\section{Authors}

K L. Thornhill, Gao Chen, Jack E. Dibb, C. Jordan, Ali Omar, E L. Winstead, Greg Schuster, A D. Clarke, Cameron McNaughton, Eric Scheuer, D R. Blake, Glen Sachse, L Gregory Huey, H B. Singh, and Bruce E. Anderson 


\title{
The impact of local sources and long-range transport on aerosol properties over the northeast U.S. region during INTEX-NA
}

\author{
K. Lee Thornhill, ${ }^{1}$ Gao Chen, ${ }^{2}$ Jack Dibb, ${ }^{3}$ Carolyn E. Jordan, ${ }^{3}$ Ali Omar, ${ }^{2}$ \\ Edward L. Winstead, ${ }^{1}$ Greg Schuster, ${ }^{2}$ Antony Clarke, ${ }^{4}$ Cameron McNaughton, ${ }^{4}$ \\ Eric Scheuer, ${ }^{3}$ Donald Blake, ${ }^{5}$ Glen Sachse, ${ }^{2}$ L. G. Huey, ${ }^{6}$ H. B. Singh, ${ }^{7}$ \\ and Bruce E. Anderson ${ }^{2}$
}

Received 16 March 2007; revised 24 August 2007; accepted 18 December 2007; published 16 April 2008.

[1] We use data collected aboard the NASA DC-8 aircraft during the summer 2004, Intercontinental Transport and Chemical Evolution Experiment over North America (INTEX-NA) field campaign to examine the origin, composition, physical and optical properties of aerosols within air masses sampled over and downwind of the northeastern U.S. We note that aerosol concentrations within the region exhibited steep vertical gradients and significant variability in both time and space. An examination of air mass chemical signatures and backward trajectories indicates that transport from four, significantly different source regions contributed to the variability: the subtropical Atlantic Ocean (AO); the U.S. west coast and eastern Pacific (WCP); the U.S. east coast and Midwestern states (EC); and northwest Canada and Alaska (CA). AO air masses were typically confined to below $2 \mathrm{~km}$ altitude, exhibited low pollutant contents, contained enhanced levels of sea salt, and were typically observed when the Bermuda High strengthened. The most common air mass present in the upper troposphere, WCP air often contained weak dust and aged pollution enhances from convective input occurring over the central part of the continent. CA air exhibited enhancements in anthropogenic pollution tracers below $2 \mathrm{~km}$ and contained some black-carbon rich haze layers between 3 and $5 \mathrm{~km}$ that could be traced to forest fires burning in western Canada and Alaska. EC air was prevalent at lower elevations throughout the study area and exhibited enhanced scattering along with elevated levels of sulfate aerosols and combustion tracers. There is an overall balance between the observed cations and anions for all cases, except EC air mass below $4 \mathrm{~km}$.

Citation: Thornhill, K. L., et al. (2008), The impact of local sources and long-range transport on aerosol properties over the northeast U.S. region during INTEX-NA, J. Geophys. Res., 113, D08201, doi:10.1029/2007JD008666.

\section{Introduction}

[2] Recent studies have shown that aerosol and gas pollutants from continental sources are transported on intercontinental scales and can influence air quality far downwind [e.g., Stohl, 2004]. This process is a major concern due to rapid industrialization and the potential impacts of the pollutants on human and ecosystem health and atmospheric radiative forcing. Aerosols, which com-

\footnotetext{
${ }^{1}$ SSAI, Hampton, Virginia, USA.

${ }^{2}$ NASA Langley Research Center, Hampton, Virginia, USA.

${ }^{3}$ Institute for the Study of Earth, Oceans, and Space, University of New Hampshire, Durham, New Hampshire, USA.

${ }^{4}$ School of Ocean and Earth Science and Technology, University of Hawaii, Hawaii, USA.

${ }^{5}$ Department of Chemistry, University of California, Irvine, California, USA.

${ }^{6}$ School of Earth and Atmospheric Sciences, Georgia Institute of Technology, Atlanta, Georgia, USA.

${ }^{7}$ NASA Ames Research Center, Moffett field, California, USA.

Copyright 2008 by the American Geophysical Union. 0148-0227/08/2007JD008666
}

pose a significant fraction of the pollutant mass exported from sources onto a regional scale, can additionally affect climate by changing cloud formation, duration and drizzle rates through their role as cloud and ice forming nuclei [Albrecht, 1989; Charlson et al., 1987; Twomey, 1977].

[3] The composition of air transported from the northeast coast of the United States over the western Atlantic is influenced by a variety of sources due to variations in meteorological flow patterns and spatial distribution of land use. It is transported offshore via cold fronts and the warm conveyor belt into the free troposphere. From there, it can be picked up and carried by the prevailing westerlies across the ocean, reaching Europe and beyond [Singh et al., 2006]. Locally, the dense urban centers along the coast are strong anthropogenic sources of sulfate aerosols and gases, while the thick forest and vegetative cover are sources of natural hydrocarbons. Combustion of fossil and bio-fuels for energy production and transportation produce carbonaceous aerosols along with $\mathrm{NO}_{\mathrm{x}}$ and $\mathrm{SO}_{\mathrm{x}}$ emissions that can result in formation of secondary sulfate and nitrate aerosols [Galloway and Whelpdale, 1987]. Further upwind, power 
plant emissions from the Ohio River Valley influence the composition of air reaching the Northeast U.S., injecting fine inorganic aerosols into the atmosphere, primarily sulfate [Hennigan et al., 2006]. Forest fires which often burn in Alaska and Canada can add additional gases and aerosols into the atmosphere which can be transported into the region. Occasionally, Asian outflow will reach the region via long-range, high altitude transport. Although this process typically is most frequent in early spring and historically not too prevalent during the summer [Singh et al., 2006], Liang et al. [2007] identified five major Asian plumes that were sampled over the eastern U.S. during July-August 2004 INTEX-NA mission. In addition to these terrestrial influences, air masses transported off the northeast coast are also influenced by sources of sea salt aerosols and biogenic aerosol-precursors.

[4] To investigate the composition and evolution of air masses exported off the U.S. east coast; NASA conducted the INTEX-NA mission as part of the International Consortium for Atmospheric Research on Transport and Transformation (ICARTT) field campaign [Fehsenfeld et al., 2006]. Conducted during July-August 2004, INTEX-NA was the latest experiment to concentrate on the North American outflow. Its predecessors include the Northeast Atlantic Regional Experiment, (NARE, Fehsenfeld et al. [1996]), the Tropospheric Aerosol Radiative Forcing Observational Experiment (TARFOX) [Russell et al., 1999], and the New England Air Quality Study (NEAQS-2002; http://www.esrl.noaa.gov/csd/NEAQS/). The natural progression of technology, including advances in satellites and computer modeling, combined with the additional aircraft that were part of ICARTT allowed the entire Northern Atlantic from the east coast of the U.S. over to Europe to be sampled and better understood.

[5] The scientific rationale for INTEX-NA as well as its objectives, flight plans, and overall instrument descriptions are presented by Singh et al. [2006]. This paper addresses the primary INTEX-NA objectives as outlined by Singh et al. [2006] of characterizing the outflow of pollution from North America and quantitatively relating atmospheric concentrations of gases and aerosols with their sources and sinks. Other INTEX-NA aerosol investigations have employed the DC-8 data to delineate the optical properties of aerosol components within urban and forest fire plumes [Clarke et al., 2007] and evaluate the impact of relative humidity on aerosol optical depths [Shinozuka et al., 2007]. We perform a detailed analysis of the DC- 8 in situ aerosol observations (along with relevant trace gases) recorded over the northeast U.S. to identify the source regions/processes responsible for regulating trace species concentrations within the sampled air masses and to establish the composition, concentration and microphysical and optical properties of aerosols within air exhausted from the continent.

\section{Experiment}

[6] The principal sampling platform for INTEX-NA was the NASA Dryden DC-8, which has a ceiling of $12 \mathrm{~km}$ and an endurance of $10 \mathrm{~h}$. The DC-8 was equipped with a variety of remote and in situ instruments to measure chemical tracers, aerosol number density, size, and composition, as well as a complement of meteorological variables.
In addition, the DC-8 data was synthesized with an ensemble of ground and satellite based measurements and modeling results to place the observations in a more regional context. There were 20 flights, each with an average duration of $8 \mathrm{~h}$, including 18 scientific flights from three intensive sites at Edwards Air Force Base, California, St. Louis, Missouri, and Portsmouth, NH. Data was collected over 43 of the 48 contiguous states of the United States. The flights had a variety of objectives, including validations of sensors on EOS-Aqua, EOS-Terra, and Aura through spiral ascents/ descents underneath the satellite in clear-air conditions, and instrument inter-comparisons with the J-31 and the NOAAP3, both participating in the NEAQS-ITCT 2004 (New England Air Quality Study-Intercontinental Transport and Chemical Transformation 2004) of the ICARTT program. A nominal flight plan included constant flight legs ranging between 15 and $60 \mathrm{~min}$ in the troposphere and lower stratosphere.

[7] A detailed meteorological summary for the entire INTEX-NA time period is given by Fuelberg et al. [2007] and is briefly summarized here. The summer of 2004 was colder than normal with a greater frequency of cold frontal passages than the climatological mean (1968-1996). Several cold fronts extended as far south as the Gulf Coast and central Florida. Alaska and northwest Canada was dominated by high pressure which favored the warm and dry conditions that led to a large number of thunderstorms and lightning which caused wildfires. The mission-averaged flow conditions reveal that the height averages at $500 \mathrm{mb}$ exhibited abnormally large amplitude waves during the summer of 2004. The trough in the eastern United States was about $40 \mathrm{~m}$ more intense, while the ridge over Alaska was about $70 \mathrm{~m}$ stronger than the climatological average. This favored conditions that led to the transport of smoke from the wildfires from Alaska and northwest Canada into the INTEX-NA study area. From anomaly analysis, the subtropical jet stream and the southern branch of the polar jet were near their climatological locations, while the northern branch of the Polar jet was about $7 \mathrm{~ms}^{-1}$ stronger than normal. Finally, one last deviation from average conditions was encountered during INTEX-NA: normally during the summer there are high pressure systems that stagnate over the northeast US and lead to the buildup of pollution from the urban centers. The buildup is then transported off the coast by cold frontal passage. It was anticipated that such a system would be encountered and sampled extensively as part of the INTEX-NA, but no such systems were encountered.

\subsection{Measurements}

[8] NASA Langley Research Center (LaRC) and the University of Hawaii (UH) collaborated to provide on-line, in situ measurements of aerosol microphysical properties (number density, size distributions, volatility) and optical parameters (scattering and absorption coefficients) aboard the NASA DC-8 using cabin-mounted instruments drawing samples from the UH solid diffuser inlet. Bulk aerosols up to $5 \mu \mathrm{m}$ in diameter were collected using filter by the University of New Hampshire (UNH) using their solid diffuser inlet. Both inlets were mounted on window plates and sample flows were regulated to maintain isokinetic flow through the inlet tips. Inlet inter-comparisons made during the spring 2003 DC-8 Inlet Characterization Experiment 
(DICE) showed that the two inlets perform nearly identical during sampling of sea salt and mineral dust under high relative humidity $(80-95 \%)$ conditions and that each efficiently transmit particles $<4 \mu \mathrm{m}$ dry diameter [Clarke et al., 2007; McNaughton et al., 2007].

[9] A set of three TSI condensation particle counters (CPC) were used to obtain the number of particles greater than $3 \mathrm{~nm}$ (ultrafine CPC, TSI-3025), and the nonvolatile and total number densities for aerosols $>10 \mathrm{~nm}$ (hot and cold CPCs, TSI-3010s). The hot CPC samples the aerosols after being passed through a 300 degree $C$ heater. In this study, the ratios of the nonvolatile to total aerosols are used. Aerosol number densities were given under ambient conditions. In the absence of high ultrafine aerosol number densities, the estimated precisions are 5\% for the hot and cold CPCs and 10\% for the ultrafine CPC. The precisions are based on the uncertainties in the flow rate and temperature measurements.

[10] Dry $(<30 \% \mathrm{RH})$ aerosol size distributions over the 0.15 to $3 \mu \mathrm{m}$ diameter range were measured with a laser optical particle counter (OPC) [Clarke et al., 2004]. The OPC was operated by cycling through three temperatures: unheated, $150^{\circ} \mathrm{C}$, and $350^{\circ} \mathrm{C}$, measuring a size distribution every three seconds [Clarke et al., 2007]. Heating sample air to $150^{\circ} \mathrm{C}$ evaporates low-temperature volatiles such as sulfuric acid and some nitrates, while heating to $350^{\circ} \mathrm{C}$ volatilizes ammonium sulfate and most organic aerosols [Clarke et al., 2004; Clarke, 1991]. For this study, the unheated OPC size distributions are used, so that all accumulation mode particles are represented. Total and submicron scattering values calculated from the OPC size distributions were compared to the scattering values obtained from the TSI nephelometer and agreed to an $\mathrm{r}^{2}$ value greater than 0.95 [Shinozuka et al., 2007].

[11] Aerosol scattering coefficients were measured at three wavelengths $(450,550$, and $700 \mathrm{~nm})$ with a TSI Integrating Nephelometer (model 3563), which integrates light scattered within a cylindrical sampling volume between $7^{\circ}$ and $170^{\circ}$. Values were corrected for size-dependent truncation errors by the methods derived by Anderson et al. [1996]. Uncertainties were estimated for instrument noise, calibration, drift and angular correction to $90 \%$ confidence following Anderson and Ogren [1998].

[12] Particle absorption coefficients at three wavelengths (470, 522, and $660 \mathrm{~nm})$ were measured with a Radiance Research Particle Soot Absorption Photometer (PSAP). The data were corrected for scattering off the filter media using the approach developed by Bond et al. [1999]. The PSAP sample filters were heated to $40^{\circ} \mathrm{C}$ to decrease the $\mathrm{RH}$ and are thus considered to be representative of dry particles. Following Bond et al. [1999], several sources of uncertainty are accounted for, including instrument accuracy, instrument precision, instrument noise, and scattering corrections.

[13] The dominant absorbing component in atmospheric aerosols at visible wavelengths is black carbon (BC) or soot. Equivalent black carbon mass is inferred from the absorption measurements by assuming a mass absorption efficiency (MAE) of $7.5 \mathrm{~m}^{2} \mathrm{~g}^{-1}$ [Bond and Bergstrom, 2006]. The conversion of absorption to equivalent black carbon is only approximate since externally mixed aerosols typically have different MAE values than internally mixed aerosols. There- fore the conversion factor is only accurate to about \pm 20 30\% [Schuster et al., 2005].

[14] Aerosol water-soluble inorganic chemical measurements were performed by the University of New Hampshire (UNH) using the dual sampling probe that they have employed on all NASA sponsored tropospheric chemistry missions since 1991, with greater detail given elsewhere [Talbot et al., 2003; Dibb et al., 1999, 2000, 2003a, 2003b]. Air is sampled through anodized aluminum curved probes with a shroud that extends $20 \mathrm{~cm}$ forward of each, allowing for nearly isoaxial sampling during flight. Air is then drawn through a $9 \mathrm{~cm}, 1 \mu \mathrm{m}$ Millipore Fluoropore Teflon filter. Flow rates are manually adjusted to be within $10 \%$ of calculated isokinetic flow during each flight leg [Dibb et $a l ., 2003 \mathrm{a}]$. Filters are subsequently processed using the procedures described by Dibb et al. [1999, 2000] to establish the bulk concentrations of water-soluble ions including tracers for anthropogenic pollution $\left(\mathrm{NO}_{3}^{-}, \mathrm{SO}_{4}^{=}\right.$, and $\left.\mathrm{NH}_{4}^{+}\right)$, biomass burning $\left(\mathrm{K}^{+}\right)$, dust $\left(\mathrm{Ca}^{2+}\right.$, and $\left.\mathrm{Mg}^{2+}\right)$, and sea salt $\left(\mathrm{Na}^{+}\right.$, and $\left.\mathrm{Cl}^{-}\right)$[Dibb et al., 2003b]. Filters are collected through a second inlet and are later analyzed for tracers of stratospheric air $\left({ }^{7} \mathrm{Be}\right.$ and $\left.{ }^{210} \mathrm{~Pb}\right)$. Samples are collected only during constant flight legs with sample times ranging from 2-27 $\mathrm{min}$. Target nominal sampling times are 5 min for altitudes between 0 and $2 \mathrm{~km}, 5$ to 7 min for $2-4 \mathrm{~km}$, and 7 to $11 \mathrm{~min}$ for $4-10 \mathrm{~km}$. For this analysis, mixing ratios (pptv) were converted to $\mu \mathrm{g} \mathrm{std}^{-3}$ (i.e., $1013 \mathrm{mb}$ and 293 $\mathrm{K})$.

\subsection{Data Sets}

[15] Two versions of the INTEX-NA final data merges are used in this study; the standard 60-s merged data set and the UNH aerosol chemical merge, in which parameters are averaged over the collection times of the UNH bulk aerosol filters. The merges have the same parameters and are a useful way of examining data with different instrument temporal resolutions. Both data sets were filtered to exclude stratospheric air by eliminating times when $\mathrm{O}_{3}$ values were in excess of $100 \mathrm{ppbv}, \mathrm{CO}$ was less than $70 \mathrm{ppbv}$, and dew point temperature was less than $-40^{\circ} \mathrm{C}$. Following Russo et al. [2003], air that exhibited an enhancement in both $\mathrm{O}_{3}$ and $\mathrm{CO}$ was considered a mixture of stratospheric and polluted air and was not removed from the data set. Aerosol and chemical species values that were reported to be below instrumental detection limits were set equal to zero to avoid artificial enhancements over background values. For the scattering coefficients, LOD values were reported for $44 \%$ of the data, whereas $5 \%$ of the UC-Irvine chemical data for gases used in this paper and 34\% of the UNH bulk aerosol data were below instrument LODs. The majority of the LOD data was observed in the middle to upper troposphere. Data obtained within and around clouds were excluded from consideration by filtering out time periods when the integrated aerosol volume density for particle sizes greater than $5 \mu \mathrm{m}$ exceeded $100 \mu \mathrm{m}^{3} \mathrm{~cm}^{-3}$.

\subsection{Air Mass Identification}

[16] On the basis of the one minute data merge file, there were 2569 tropospheric data points collected within the study area defined in Figure 1. Initial analysis of this data showed large variability in both gas phase tracers (e.g., CO, $\mathrm{SO}_{2}$ ) as well as in aerosol bulk properties (e.g., total dry 


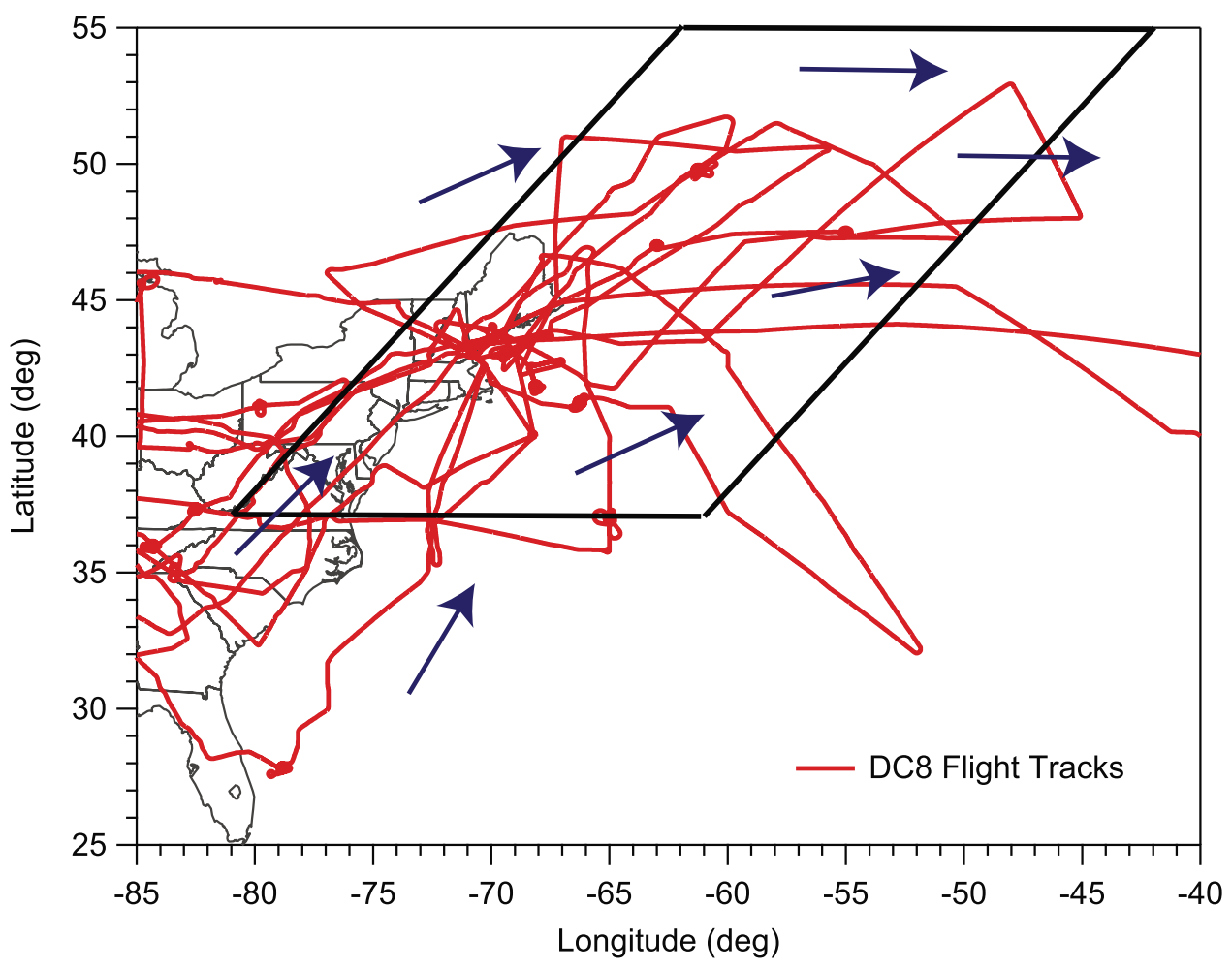

Figure 1. The study area shown as a parallelograms laid over the DC-8 flight tracks (red) during the INTEX-NA mission. The blue arrows show the mean $850 \mathrm{mb}$ winds during the mission.

volume and total scattering). Many species, especially those associated with aerosols, showed strong vertical gradients. However, we were unable to discern any systematic trends in species concentrations or characteristics with longitude or latitude, which suggests that the observed variability was more likely driven by transport from local and distant source regions. To identify the relevant aerosol source processes and transport pathways, we examined the meteorological back trajectories and the compositional signatures of each point within the merged data set. The Florida State University (FSU) kinematic air mass trajectory model was used to calculate one-minute resolution, five-day back trajectories for each of the DC-8 level flight legs. The trajectories are derived from three-component winds provided by the National Weather Service's Global Forecast System (GFS). A cubic-spline interpolation was used to create $5-\mathrm{mb}$ vertical layers between 1000 and $50 \mathrm{mb}$. The data was then linearly interpolated to make the 1-minute flight level trajectories. Further information on the trajectory techniques, including a comparison between kinematic and isentropic trajectories are given by Fuelberg et al. [1996].

[17] Although trajectory analyses are limited in absolute accuracy [Fuelberg et al., 2000; Stohl et al., 1995; Stohl, 1998], they are useful for determining the broad source categories for our data sets. To investigate the possible source regions, trajectories were grouped according to the averaging time for the aerosol chemical data, which was nominally six trajectories below $1 \mathrm{~km}$, nine trajectories between 1 and $6 \mathrm{~km}$, and seventeen trajectories above $6 \mathrm{~km}$ [Dibb et al., 2003b]. From this analysis, four primary source regions were identified: Atlantic Ocean (AO), East Coast (EC), West Coast/Pacific (WCP), and Canada/Alaska
(CA) (Figure 2). In order for a sample (on the UNH timescale) to be considered as originating from a source region, all of the trajectories for that sample had to converge to the same region. If all of the trajectories did not converge to the same area, they were considered mixed and were excluded from further analysis. The final data set, from the UNH merge, was composed of 24 samples from the AO region, 74 from the EC region, 55 from the WCP region, and 69 from the CA region. The altitude of the trajectory corresponds to the aircraft sampling altitude, not where it has been over the last five days. Some vertical transport over the previous five days was allowed, but deep convection cases are excluded to prevent inclusion of boundary layer air downwind of the injection point. The vertical transport of the air parcels into the Northeast U.S. is shown in Figure 2 for each source region.

[18] As stated earlier, there are 2659 1-min data points collected within the region of interest, which represents over $44 \mathrm{~h}$ of airborne sampling. It was possible to assign $47 \%$ of these points to one of the four air mass types. This allows us to use gas phase tracers to further characterize the air masses identified from back trajectory analysis. Recall that one minute merge data offers the higher temporal and spatial resolution for airborne sampling which is more suitable for air mass characterization than the $\mathrm{UNH}$ based merge. Figure 3 contrasts the vertical profiles of 6 gas phase tracers among the four identified air mass types and the overall data set. The selected species can well represent the various combustion emissions, i.e., $\mathrm{CO}, \mathrm{NO}_{2}, \mathrm{SO}_{2}$, and $\mathrm{CH}_{3} \mathrm{CN}$, and oxidation products i.e., $\mathrm{HNO}_{3}$ and isopropyl nitrate (measurement of these gas phase species are given by Sachse et al. [1987], Bertram et al. [2007], Kim et al. 

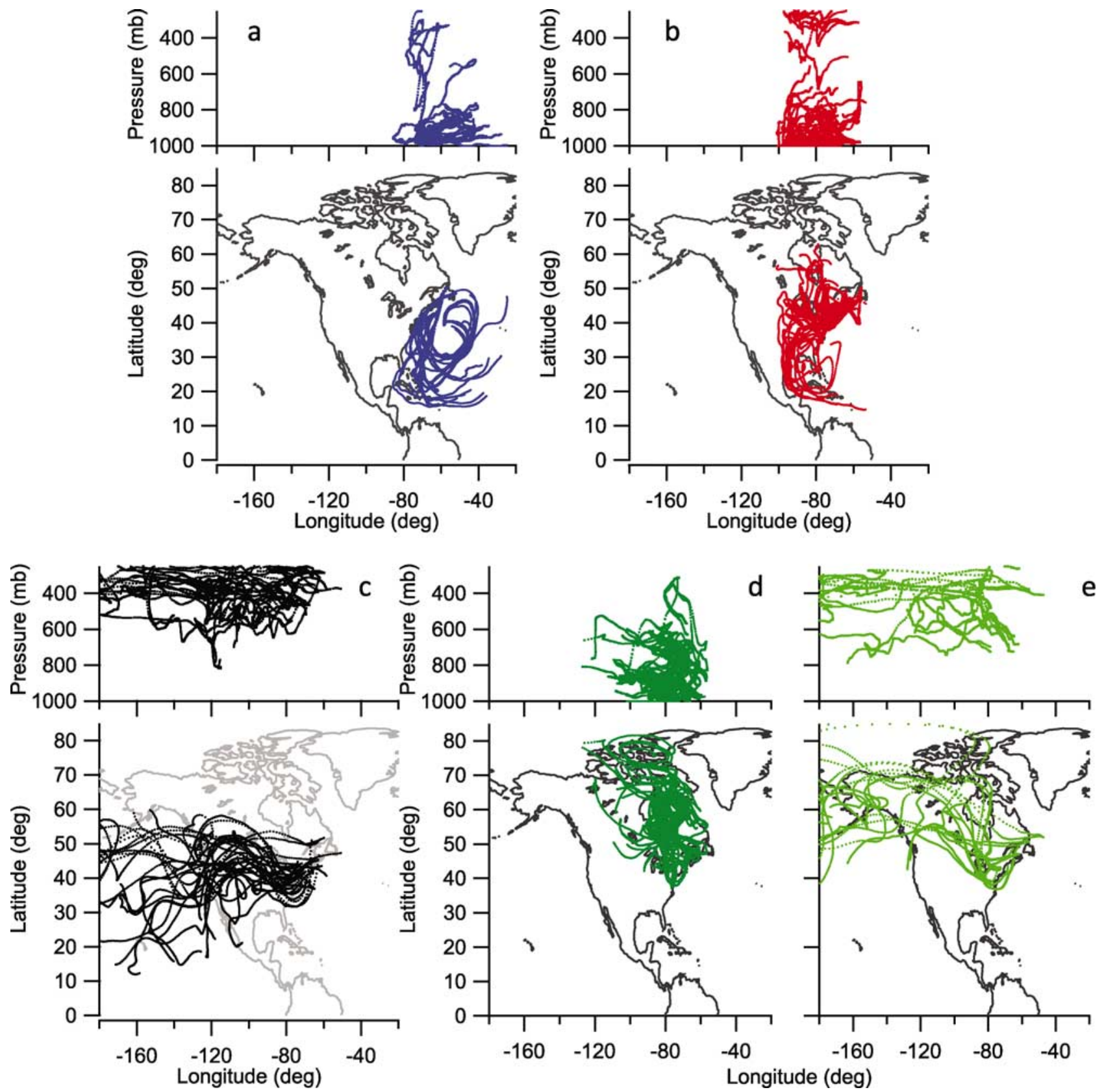

Figure 2. Sample back trajectories illustrating the four primary air mass source regions, (a) Atlantic Ocean (clean, marine air), (b) East Coast, (c) West Coast/Pacific, and (d, e) Canadian/Alaskan (eastern Canada and western Canada/Alaska) along with the vertical transport of each parcel.

[2007], Huey et al. [2004], Singh et al. [2003], Talbot et al. [1999], and Blake et al. [2003]). High levels of the first four tracers are likely to be an indication of strong influence from direct anthropogenic emissions, whereas enhancements in $\mathrm{HNO}_{3}$ and isopropyl nitrate tend suggests somewhat more aged pollution in which a significant portion of primary pollutants have been oxidized.

[19] Most of the samples representing the AO grouping were collected in the boundary layer (BL) and, as expected, exhibited the lowest mixing ratios for 5 out of 6 tracers presented in Figure 3. Elevated levels of $\mathrm{SO}_{2}$ in association with low levels of $\mathrm{CO}$ and $\mathrm{NO}_{2}$ within these air masses is likely due to the influence of ship emissions, as ships generally produce low $\mathrm{CO}$ emissions and the lifetime of $\mathrm{NO}_{\mathrm{x}}$ within exhaust plumes is rather short [Chen et al., 2005]. As discussed below, the bulk aerosol chemical composition measurements show the highest sea-salt content in the samples collected in the AO air masses.

[20] In contrast to the AO maritime air masses, the highest readings of $\mathrm{CO}, \mathrm{NO}_{2}, \mathrm{SO}_{2}, \mathrm{HNO}_{3}$, and isopropyl nitrate (a secondary anthropogenic organic compound that is typically correlated with particulate organic matter) were recorded between 0 and $1 \mathrm{~km}$ within air masses originating over the U.S. east coast. Enhancements in these tracers in urban air masses are caused by a variety of sources including power plant and industrial emissions and vehic- 

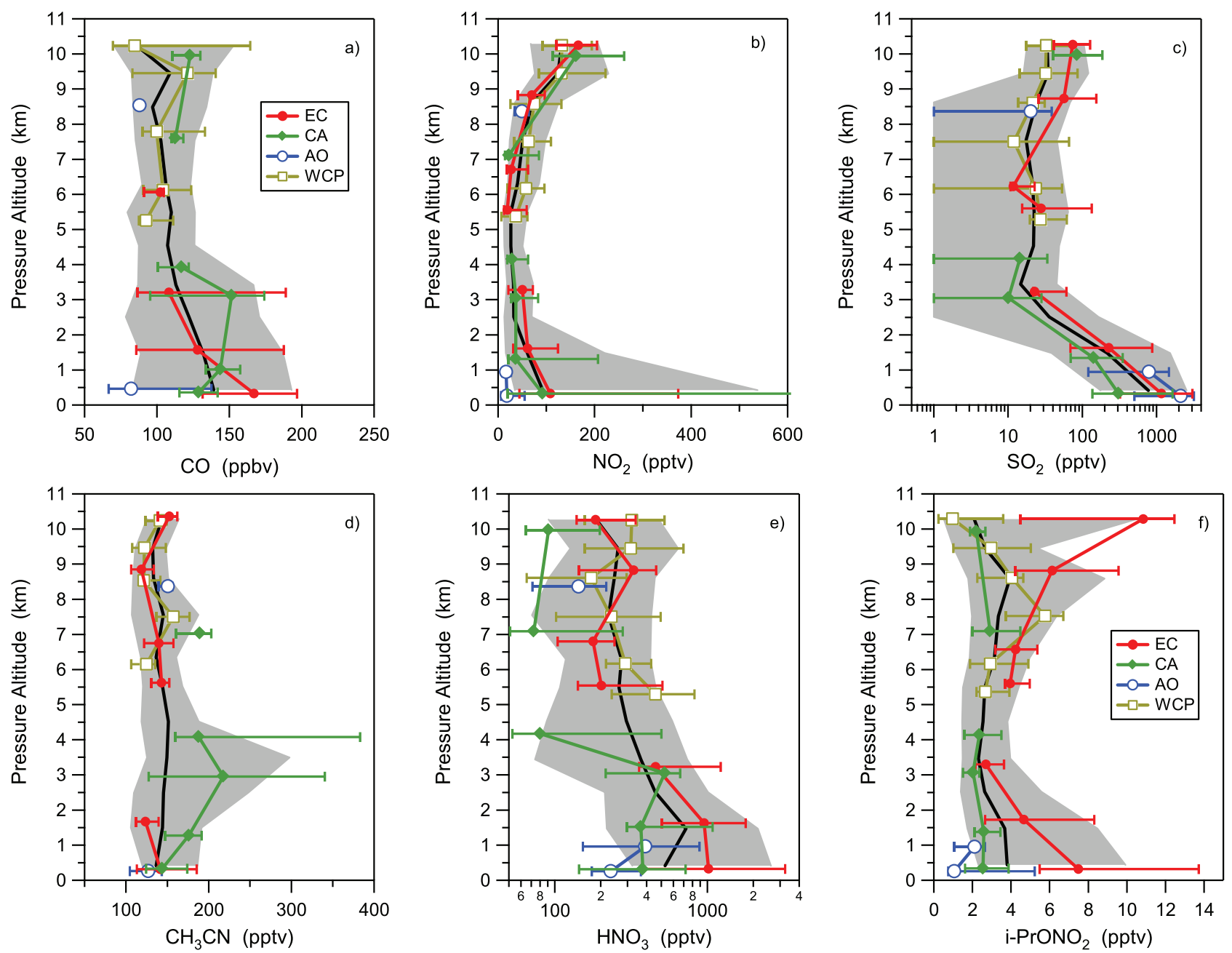

Figure 3. Vertical profiles of: (a) $\mathrm{CO}$, (b) $\mathrm{NO}_{2}$, (c) $\mathrm{SO}_{2}$, (d) $\mathrm{CH}_{3} \mathrm{CN}$, (e) $\mathrm{HNO}_{3}$, and (f) isopropyl nitrate for the East Coast, Canadian/Alaskan, Atlantic Ocean, and West Coast/Pacific air masses. The black line denotes median values and the edges of the shaded area represent the 10th and 90th percentiles and for the overall data set. The symbols represent the median values and error bars extend to cover the 10th and 90th percentiles of each data grouping.

ular exhaust. Because intense convection occurred over and upwind of the study area, it was not surprising to the see some of the less soluble pollutants (e.g., $\mathrm{NO}_{2}$ and isopropyl nitrate) being transported to the mid and upper troposphere in the EC cases.

[21] The CA air masses were typically influenced by two different types of emissions. Samples collected below $2 \mathrm{~km}$ exhibited anthropogenic emission signatures, i.e., elevated levels of $\mathrm{CO}, \mathrm{NO}_{2}$, and $\mathrm{HNO}_{3}$, but $\mathrm{SO}_{2}$ levels that were significantly lower than the median value for the overall data set. For the altitudes ranging from 2 to $4 \mathrm{~km}$, these air masses showed marked enhancements in $\mathrm{CO}$ and $\mathrm{CH}_{3} \mathrm{CN}$, the latter being a well documented tracer for biomass burning. Air parcels with WCP origins were the most common air mass type sampled in the mid to upper troposphere during the project and showed indications of aged pollution in the form of elevated levels of $\mathrm{HNO}_{3}$ and isopropyl nitrate plus enrichments in coarse mode aerosols that may have been related to convective input of dust over the mid-continent region. However, it is difficult to ascribe unique chemical tracers to this case because most species were neither enhanced nor especially depleted. Finally, it should be noted here that the AO, CA and EC source regions were also identified in a similar air mass characterization study performed of data recorded at an island site off the New England coast during the INTEX-NA time period [Chen et al., 2007].

\section{Results and Discussion}

[22] Figure 4 displays vertical profiles for each of the four air mass types of median values and statistics for dry particle volume density, the sum of water-soluble ion mass (excluding POM), and total scattering coefficients at $550 \mathrm{~nm}$. Values were calculated with $1-\mathrm{km}$ resolution bins for the $0-2 \mathrm{~km}$ height range and $2-\mathrm{km}$ resolution bins for $2-10 \mathrm{~km}$ range. Volume density and scattering coefficient statistics were calculated using the one minute merge data file, which provided most altitude bins with over 30 individual points. Vertical profiles of water-soluble ion mass concentrations are presented in Figure 5. Taken together, the data indicate that aerosol mass loading and bulk optical properties 

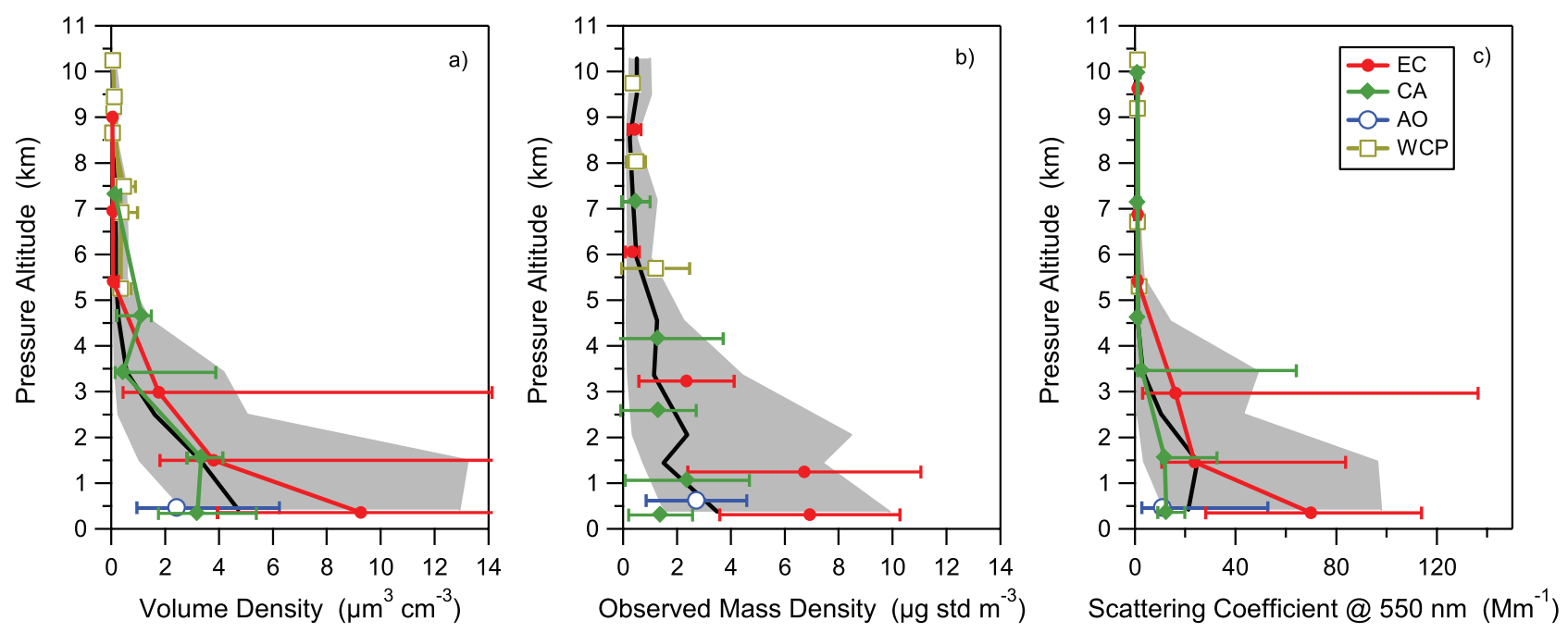

Figure 4. Vertical profiles of (a) aerosol volume density, (b) observed mass density (excluding POM), and (c) scattering coefficient at $550 \mathrm{~nm}$. The median value of the all data is shown by the black line and the corresponding 10th and 90th percentiles are displayed as the edges of the shaded areas. For panel (a) and (c), symbols denote median values and error bars represent the 10th and 90th percentiles. For panel (b), symbols are averages and errors bars represent +1 standard deviation.

generally decreased with increasing altitude for each of the four air mass types. Further, the scattering (Figure 4c) profile suggests that, except for a few isolated haze layers encountered at high altitude, most significant aerosol direct radiative effects and essentially all the column optical depth were confined to below $4 \mathrm{~km}$. Among the source regions, the EC data has the largest aerosol loading and steepest vertical gradients (Figures 4 and 5). In contrast, CA air masses have much lower aerosol loading, about a factor of 4 lower than the EC, and more gradual vertical gradients due to contributions from forest fire plumes in the 3 to $4 \mathrm{~km}$ height regime for many of the cases (note enhanced levels of $\mathrm{K}^{+}$, a biomass burning tracer, in Figure 5). On the basis of the observed vertical trends shown in Figures 4 and 5, we opted to divide the data vertically into 3 altitude bins for further analysis: $0-2 \mathrm{~km}, 2-4 \mathrm{~km}$, and $4-10 \mathrm{~km}$. This is to build robust statistics with all available data to characterize the observed aerosol microphysical, optical, and chemical properties in a consistent manner.

\subsection{Optical and Microphysical Measurements}

[23] Table 1 summarizes some of the important parameters describing aerosol loading and optical properties in terms of median, 10th and 90th percentile values. The volume $(\mathrm{V})$ and number $(\mathrm{N})$ density statistics are derived from OPC size distributions and total condensation particle counter (CPC) measurements for diameters $>10 \mathrm{~nm}$, respectively. As discussed in the measurement section, the hot/ cold ratio represents the fraction of particles that remain after heating the sample to $300^{\circ} \mathrm{C}$. ECCN refers to the estimated cloud condensation nuclei, which we define as the number density of particles larger than $200 \mathrm{~nm}$ in diameter. This definition is based on the assumption that most particles in this size range can be activated at modest supersaturation levels, regardless of their composition [Pruppacher and Klett, 1997]. It is acknowledged here that this is likely to be a lower end estimate. The optical parameters given here are hydroscopic growth factor, $(\mathrm{f}(\mathrm{RH})$ ), which is the ratio of $550 \mathrm{~nm}$ scattering coefficients at 85 and 30\% relative humidity; total scattering coefficient at $550 \mathrm{~nm}$; total absorption coefficient at $530 \mathrm{~nm}$; single scattering albedo at $530 \mathrm{~nm}$; and angstrom exponents for scattering and absorption measured at 450 and $700 \mathrm{~nm}$, and 466 and $660 \mathrm{~nm}$, respectively.

[24] For the 0-2 km altitude range, the EC grouping had the highest aerosol volume and number density, followed by CA air masses; both exhibited significantly larger values for these parameters than did the AO air masses, which may be considered as representative of background conditions. Median values for the entire data set typically reside between those for the EC and CA cases, suggesting that these regions may have had the greatest overall impact on atmospheric composition within the study area. Although the non-volatile number fraction for the groupings are relatively constant, the $\mathrm{AO}$ air masses contained somewhat lower number densities of refractory, non-absorbing particles that were, judging from corresponding size distribution and composition data, most likely sea salt. In contrast, the EC and CA air masses contained enhanced levels of submicron (see Figure 6 and discussions later in the text), nonvolatile aerosols that were probably introduced by combustion processes. Absorption coefficients were in general fairly small, represented by an SSA range for the entire data set of $0.951-0.984$. Interestingly, the strongest absorption was seen in the CA grouping, which exhibited a 10th percentile SSA value of 0.900 . Moreover, scattering coefficients were highly correlated with the volume density. Clarke et al. [2007] has commented on reaching 90\% of consistency between scattering values calculated from the OPC aerosol size distribution and nephelometer observed values. As for the angstrom exponents, Table 1 shows strong short wavelength preference for scattering coefficient for all cases (somewhat weaker for the Atlantic air mass), which suggests dominance of small particles. The absorp- 

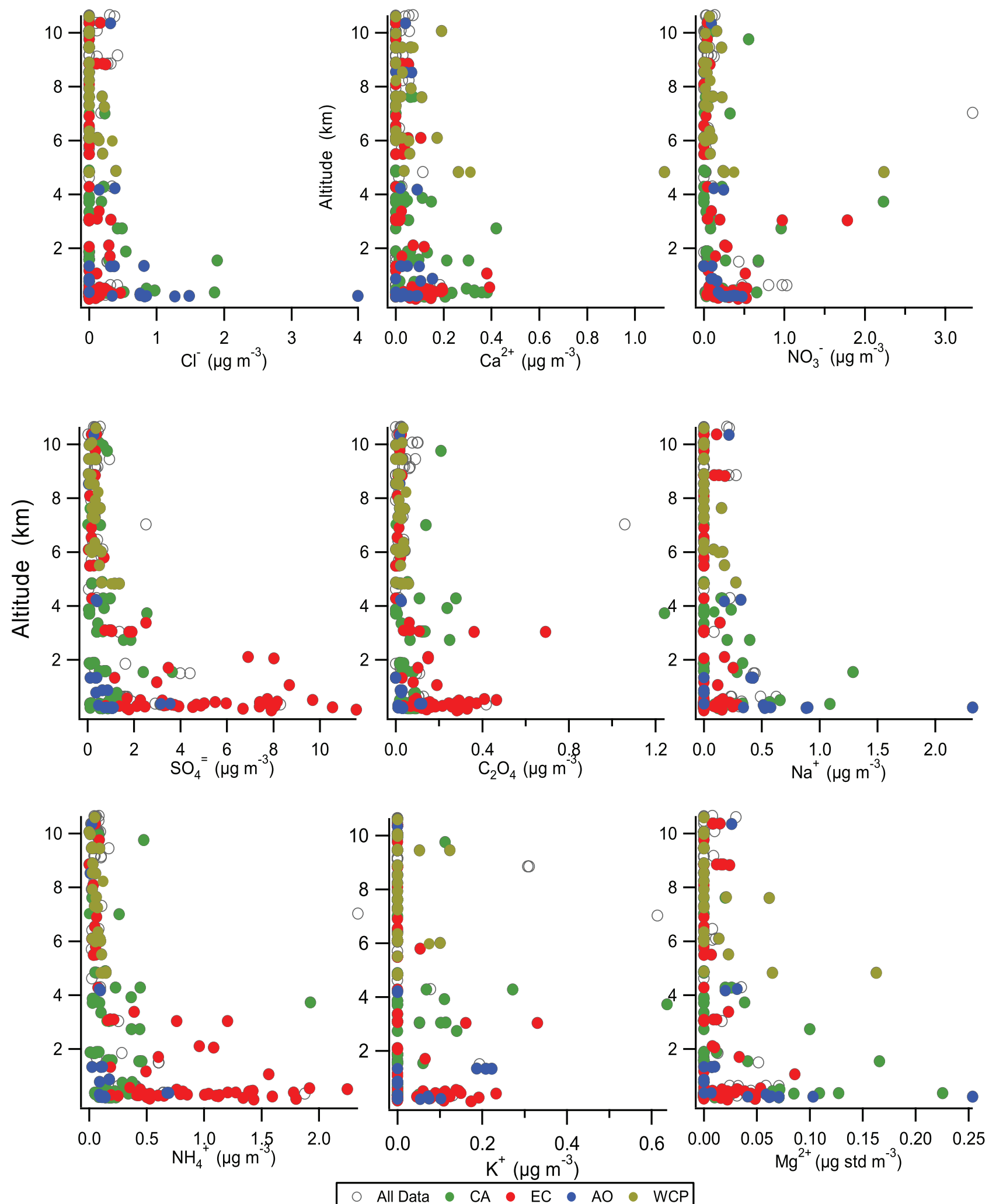

All Data $\bullet \mathrm{CA} \bullet \mathrm{EC} \bullet \mathrm{AO} \bullet \mathrm{WCP}$

Figure 5. Vertical profiles of soluble ion species for each of the air mass source regions as well as the overall data set.

tion angstrom exponents show similar, but much weaker trends. As for potential aerosol indirect effects, EC air masses contained substantially higher ECCN concentrations than the other cases, equivalent to over $20 \%$ of the total number of particles (for median values). CA air contained almost twice as many ECCN as AO air, but these only represented about $7 \%$ of the total particles present in the air mass. Overall, the ECCN is about $15 \%$ of the total particle 
Table 1. Summary of Observed Aerosol Microphysical and Optical Properties ${ }^{\mathrm{a}}$

\begin{tabular}{|c|c|c|c|c|c|c|c|c|c|c|c|}
\hline Alt & Air Mass & $\begin{array}{c}\mathrm{V}^{\mathrm{b}} \\
\mu \mathrm{m}^{3} \mathrm{~cm}^{-3}\end{array}$ & $\mathrm{~N}, \mathrm{~cm}^{-3}$ & hot/cold & $\begin{array}{l}\mathrm{ECCN}^{\mathrm{c}}, \\
\mathrm{cm}^{-3}\end{array}$ & $\mathrm{~F}, \mathrm{RH}$ & $\begin{array}{c}\text { Scatt550, } \\
\mathrm{Mm}^{-1}\end{array}$ & $\begin{array}{c}\text { ABS530, } \\
\mathrm{Mm}^{-1}\end{array}$ & SSA & $\mathrm{AE}_{\text {scatt }}{ }^{\mathrm{d}}$ & $\mathrm{AE}_{\mathrm{abs}}{ }^{\mathrm{e}}$ \\
\hline \multirow[t]{4}{*}{$0-2 \mathrm{~km}$} & $\mathrm{EC}$ & $\begin{array}{c}9.05 \\
(3.27,15.7)\end{array}$ & $\begin{array}{c}2481 \\
(1173,5111)\end{array}$ & $\begin{array}{c}0.76 \\
(0.69,0.79)\end{array}$ & $\begin{array}{c}514 \\
(199,855)\end{array}$ & $\begin{array}{c}1.78 \\
(1.58,2.12)\end{array}$ & $\begin{array}{c}66 \\
(22,111)\end{array}$ & $\begin{array}{c}2 \\
(1,4)\end{array}$ & $\begin{array}{c}0.968 \\
(0.954 \\
0.979)\end{array}$ & $\begin{array}{c}2.14 \\
(1.81,2.42)\end{array}$ & $\begin{array}{c}0.51 \\
(-0.20,0.84)\end{array}$ \\
\hline & $\mathrm{CA}$ & $\begin{array}{c}3.25 \\
(1.80,5.27)\end{array}$ & $\begin{array}{c}1964 \\
(618,8423)\end{array}$ & $\begin{array}{c}0.73 \\
(0.44,0.76)\end{array}$ & $\begin{array}{c}133 \\
(82,214)\end{array}$ & $\begin{array}{c}1.72 \\
(1.52,1.97)\end{array}$ & $\begin{array}{c}12 \\
(9,20)\end{array}$ & $\begin{array}{c}1 \\
(\mathrm{LOD}, 1)\end{array}$ & $\begin{array}{c}0.958 \\
(0.900, \\
0.981)\end{array}$ & $\begin{array}{c}2.27 \\
(1.76,2.57)\end{array}$ & $\begin{array}{c}0.66 \\
0.00,1.19)\end{array}$ \\
\hline & $\mathrm{AO}$ & $\begin{array}{c}2.42 \\
(0.95,6.18)\end{array}$ & $\begin{array}{c}466 \\
(345,1177)\end{array}$ & $\begin{array}{c}0.58 \\
(0.37,0.71)\end{array}$ & $\begin{array}{c}72 \\
(33,324)\end{array}$ & $\begin{array}{c}1.76 \\
(1.43,2.49)\end{array}$ & $\begin{array}{c}11 \\
(3,53)\end{array}$ & LOD & LOD & $\begin{array}{c}1.43 \\
(0.68,2.02)\end{array}$ & $\begin{array}{c}0.00 \\
(-0.38,0.60)\end{array}$ \\
\hline & $\begin{array}{l}\text { WCP } \\
\text { all data }\end{array}$ & $\begin{array}{c}4.14 \\
(2.42,12.9)\end{array}$ & $\begin{array}{c}1862 \\
(941,5454)\end{array}$ & $\begin{array}{c}0.73 \\
(0.66,0.79)\end{array}$ & $\begin{array}{c}202 \\
(62,754)\end{array}$ & $\begin{array}{c}1.81 \\
(1.67,2.27)\end{array}$ & $\begin{array}{c}22 \\
(11,97)\end{array}$ & $\begin{array}{c}1 \\
(1,4)\end{array}$ & $\begin{array}{l}0.965 \\
(0.951, \\
0.984)\end{array}$ & $\begin{array}{c}2.08 \\
(1.85,2.52)\end{array}$ & $\begin{array}{c}0.57 \\
(0.09,1.19)\end{array}$ \\
\hline \multirow[t]{3}{*}{$2-4 \mathrm{~km}$} & $\mathrm{EC}$ & $\begin{array}{c}1.77 \\
(0.45,14.1)\end{array}$ & $\begin{array}{c}583 \\
(486,981)\end{array}$ & $\begin{array}{c}0.70 \\
(0.58,0.79)\end{array}$ & $\begin{array}{c}78 \\
(27,374)\end{array}$ & $\begin{array}{c}1.65 \\
(1.37,2.39)\end{array}$ & $\begin{array}{c}16 \\
(3,136)\end{array}$ & $\begin{array}{c}1 \\
(\mathrm{LOD}, 7)\end{array}$ & $\begin{array}{c}0.954 \\
(0.932, \\
0.977)\end{array}$ & $\begin{array}{c}1.60 \\
(1.31,2.14)\end{array}$ & $\begin{array}{c}1.19 \\
(0.00,1.55)\end{array}$ \\
\hline & $\mathrm{CA}$ & $\begin{array}{c}0.45 \\
(0.14,3.88)\end{array}$ & $\begin{array}{c}631 \\
(400,952)\end{array}$ & $\begin{array}{c}0.64 \\
(0.41,0.79)\end{array}$ & $\begin{array}{c}15 \\
(7,165)\end{array}$ & $\begin{array}{c}1.31 \\
(1.27,1.44)\end{array}$ & $\begin{array}{c}3 \\
(\mathrm{LOD}, 64)\end{array}$ & $\begin{array}{c}1 \\
(\mathrm{LOD}, 3)\end{array}$ & $\begin{array}{c}0.94 \\
(0.859, \\
0.974)\end{array}$ & $\begin{array}{c}1.62 \\
(1.26,1.83)\end{array}$ & $\begin{array}{c}1.26 \\
(0.00,2.04)\end{array}$ \\
\hline & $\begin{array}{c}\text { AO } \\
\text { WCP } \\
\text { all data }\end{array}$ & $\begin{array}{c}0.91 \\
(0.14,4.88)\end{array}$ & $\begin{array}{c}594 \\
(379,1010)\end{array}$ & $\begin{array}{c}0.67 \\
(0.44,0.78)\end{array}$ & $\begin{array}{c}44 \\
(7,230)\end{array}$ & $\begin{array}{c}1.70 \\
(1.30,2.41)\end{array}$ & $\begin{array}{c}5 \\
\text { (LOD, } 44)\end{array}$ & $\begin{array}{c}1 \\
(\mathrm{LOD}, 4)\end{array}$ & $\begin{array}{l}0.937 \\
(0.783, \\
0.972)\end{array}$ & $\begin{array}{c}1.77 \\
(1.30,2.27)\end{array}$ & $\begin{array}{c}1.19 \\
(0.00,2.04)\end{array}$ \\
\hline \multirow[t]{5}{*}{$4-12 \mathrm{~km}$} & $\mathrm{EC}$ & $\begin{array}{c}0.06 \\
(0.03,0.16) \\
0.20\end{array}$ & $\begin{array}{c}2159 \\
(544,8390) \\
983\end{array}$ & $\begin{array}{c}0.33 \\
(0.08,0.53) \\
0.44\end{array}$ & $\begin{array}{c}1 \\
(0.4,5)\end{array}$ & 132 & LOD & LOD & LOD & LOD & LOD \\
\hline & & $\begin{array}{c}(0.13,1.46) \\
0.03\end{array}$ & $\begin{array}{c}(449,2234) \\
700\end{array}$ & $\begin{array}{c}(0.27,0.68) \\
0.52\end{array}$ & $(6,11)$ & $(1.27,1.43)$ & (LOD, 16) & & & & \\
\hline & $\mathrm{AO}$ & $\begin{array}{c}0.03 \\
(0.02,0.03)\end{array}$ & $\begin{array}{c}700 \\
(501,6046)\end{array}$ & $\begin{array}{c}0.52 \\
(0.04,0.72)\end{array}$ & & & LOD & LOD & LOD & LOD & LOD \\
\hline & WCP & $\begin{array}{c}0.17 \\
(0.04,0.76)\end{array}$ & $\begin{array}{c}941 \\
(389,4919)\end{array}$ & $\begin{array}{c}0.31 \\
(0.10,0.76)\end{array}$ & $\begin{array}{c}4 \\
(1,15)\end{array}$ & & LOD & LOD & LOD & LOD & LOD \\
\hline & all data & $\begin{array}{c}0.14 \\
(0.03,0.63)\end{array}$ & $\begin{array}{c}977 \\
(440,3676)\end{array}$ & $\begin{array}{c}0.36 \\
(0.11,0.69)\end{array}$ & $\begin{array}{c}5 \\
(1,17)\end{array}$ & $\begin{array}{c}1.32 \\
(1.27,1.70)\end{array}$ & $\begin{array}{c}\text { LOD } \\
(\mathrm{LOD}, 2)\end{array}$ & LOD & LOD & LOD & LOD \\
\hline
\end{tabular}

${ }^{\mathrm{a}}$ Median values given in the top line, 10th and 90th percentiles given inside parentheses.

${ }^{\mathrm{b}}$ Dry volume density.

${ }^{c}$ Estimated CCN, defined as total number of particle with diameter larger than $200 \mathrm{~nm}$, likely to be a lower limit estimate of CCN.

${ }^{\mathrm{d}}$ Scattering angstrom exponent for scattering for the wavelength range of 450 to $700 \mathrm{~nm}$.

${ }^{\mathrm{e}}$ Absorption angstrom exponent for the wavelength range of 470 to $660 \mathrm{~nm}$.

number density. Median $\mathrm{f}(\mathrm{RH})$ values for the three air masses present within the $0-2 \mathrm{~km}$ altitude range were about the same, but the AO grouping showed the greatest $90 \%$ value, reflecting its higher relative concentration of sea salt particles.

[25] To explore the possible sources of the observed aerosols, we conducted a correlation analysis between the
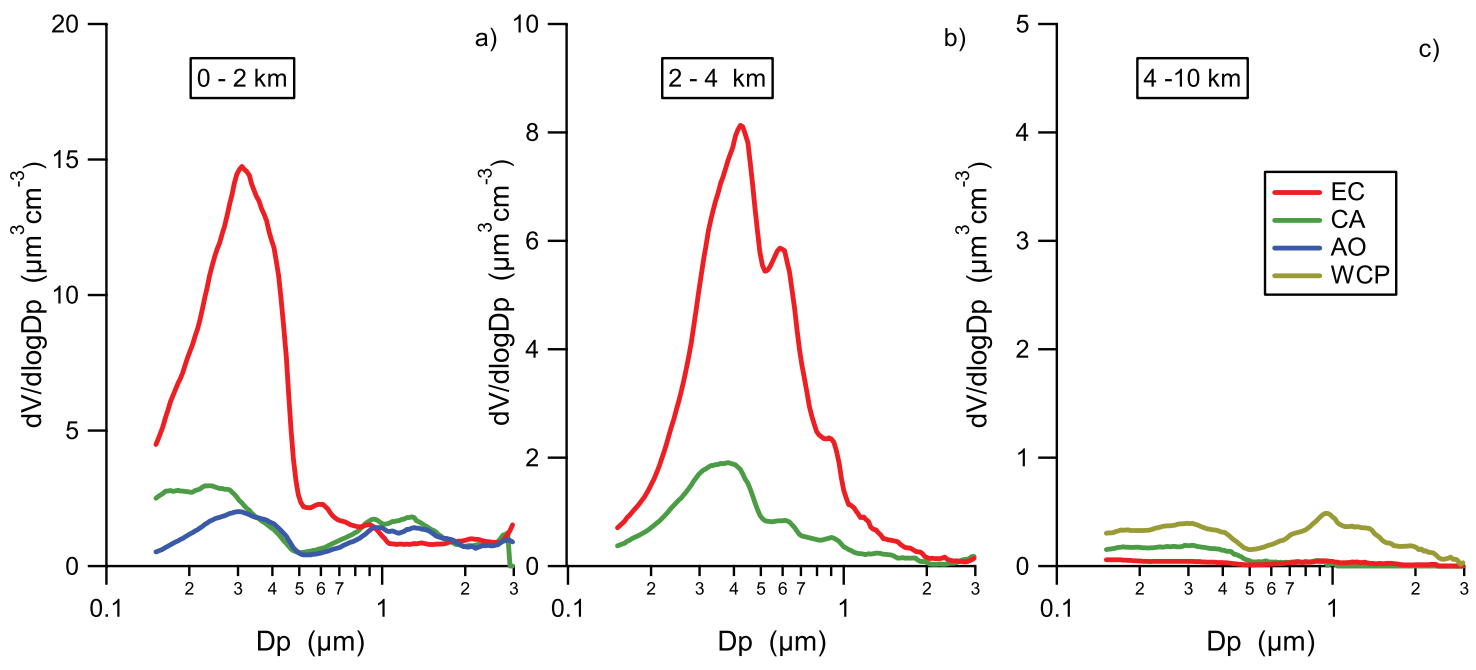

Figure 6. Aerosol volume based size distribution. Note: The $y$ axis scales are different for the three panels. 
aerosol properties and gas phase tracers. Strong correlations were seen between the total scattering and $\mathrm{CO}$ mixing ratio for both EC and CA air masses with $\mathrm{R}^{2}$ values of 0.68 and 0.58 , respectively. This suggests both cases were highly influenced by anthropogenic emissions. The difference between these air masses is that the CA air masses had stronger correlation between scattering and isopropyl nitrate with an $\mathrm{R}^{2}$ value of 0.57 . EC air masses exhibited an overall $\mathrm{R}^{2}$ of 0.40 , although much higher correlations between these parameters were seen for some highly scattering layers. These correlations with isopropyl nitrate suggest particulate organic matter likely makes a larger relative contribution to aerosol mass loading in the CA air masses. Finally, we note that no significant correlation was found between $\mathrm{SO}_{2}$ and scattering for any of the air masses.

[26] As noted above, overall aerosol loading in the $2-4 \mathrm{~km}$ altitude range was significantly less than estimated for the $0-2 \mathrm{~km}$ range. The volume density declined by about a factor of 4 to 5 and the number density deceased by a factor of 3-4. The somewhat lower values of the hot/cold ratio suggest that the aerosol is likely to be more aged and to contain a higher relative fraction of components produced by in situ oxidation processes. The smaller ECCN concentrations can probably be linked to the loss of the large particles through precipitation scavenging and surface deposition. There is a noticeable difference in $\mathrm{f}(\mathrm{RH})$ values between the EC and CA groupings, which likely reflects the different relative proportions of sulfate and POM in the two cases in this height regime. Both scattering and absorption coefficients decreased relative to the lowest altitude bin, which reflects the lower concentrations of accumulation mode aerosols as well as the lesser influence of local pollution sources. The SSA values are somewhat lower than those for 0-2 km, but there are significant overlaps for the range of variation. Angstrom Exponents are lower for the scattering signifying weaker wavelength dependence due to a greater contribution from larger particles. The absorption angstrom exponents nearly doubled, which may indicate a greater relative contribution of slightly absorbing organic carbon ("blue" carbon) in this height range. The scattering Angstrom exponent values shown on Table 1 for both $0-2$ and 2-4 km bins are generally consistent with those for the "Plume" cases reported by Clarke et al. [2007]. By contrast, those authors show absorption coefficients are about twice higher than the values derived from this study. It is noted that the 90th percentile value for CA air mass at 2-4 km matches well with the biomass burning plume absorption Angstrom Exponent value estimated by Clarke et al. [2007]. This supports the notion that the CA air mass, at least partially, was impacted by biomass burning emissions.

[27] In the EC 2 to $4 \mathrm{~km}$ altitude range, the scattering coefficients were strongly correlated with both $\mathrm{CO}\left(\mathrm{R}^{2}=\right.$ $0.93)$ and isopropyl nitrate $\left(\mathrm{R}^{2}=0.78\right)$. This suggests that the aerosols were anthropogenic in nature and the aging processes may have led to a more important role for POM. For the $\mathrm{CA}$ air masses, scattering was strongly correlated with $\mathrm{CH}_{3} \mathrm{CN}\left(\mathrm{R}^{2}=0.92\right)$, a biomass burning tracer, especially within readily identifiable forest fire plumes. This suggests that the elevated scattering observation is mostly due to the sampling of biomass burning plumes. The overall low median scattering values can interpreted as (1) biomass burning influence is not widely spread, (2) aircraft sampling was not representative, or (3) a combination of (1) and (2).

[28] For the highest altitude regime, $4-10 \mathrm{~km}$, the scattering and absorption coefficients mostly approached the limit of detection levels and thus, it is not possible report robust and representative estimates of SSA and angstrom exponents. The aerosol volume densities declined to less than $5-10 \%$ of the levels recorded in $0-2 \mathrm{~km}$. In contrast, total aerosol number densities remained quite significant, even higher than the $2-4 \mathrm{~km}$ regime, which likely reflects the contribution of freshly nucleated particles in the mid- to upper-troposphere. Indeed, the highest number density was observed in EC air masses that exhibited very low ECCN concentrations, which is consistent with particle nucleation taking place in areas devoid of existing aerosol surface area. WCP and CA air masses typically contained $4-7 \mathrm{~cm}^{-3}$ ECCN, but overall particle number densities that were less than half those observed in the EC group.

[29] Figure 6 displays average aerosol volume-based size distributions for the air mass types as a function of altitude. For the lowest altitude bin, the EC air mass exhibits a primary mode around $0.3 \mu \mathrm{m}$ diameter, which the analysis of Clarke et al. [2007] indicates is composed of ion species related to anthropogenic emissions. The AO air mass, however, has modes at 0.3 and $1.3 \mu \mathrm{m}$, where the smaller size mode may reflect some levels of influence of the outflow from the North America continent, whereas the coarse mode is most likely related to sea salt contributions. The CA size distribution exhibits modes at $0.2 \mu \mathrm{m}$ and another at $1.2 \mu \mathrm{m}$ that are probably related to combustion emissions and dust, respectively. For the $2-4 \mathrm{~km}$ altitude range, the $\mathrm{EC}$ and $\mathrm{CA}$ size distributions exhibit several modes in the submicron particle size range. This may suggest that the air masses contained a complex mixture of different aerosol types with different ages and composition. The EC and CA size distributions difference between $0-2 \mathrm{~km}$ and $2-4 \mathrm{~km}$ is consistent with scattering angstrom exponent difference which has significant higher values in the $0-2 \mathrm{~km}$, suggesting larger contribution from the small particles. For the highest altitude bin, we note that EC grouping exhibited the smallest aerosol volumes, but the largest total number densities. This is likely the result of the convective transport removal of the large particles and formation of new particles. The CA air mass has one mode around $0.3 \mu \mathrm{m}$. It can be hypothesized that this feature possibly results from convective transport of both urban/ industrial pollution and biomass burning emissions. In the WCP air mass case, the bimodal size distribution may be interpreted as a mixture of pollution and dust.

\subsection{Water-Soluble Ions}

[30] Table 2a summarizes the UNH filter measurements of the soluble ions $\mathrm{SO}_{4}^{=}, \mathrm{NO}_{3}^{-}, \mathrm{NH}_{4}^{+}$, sea-salt (sum of $\mathrm{Na}^{+}$ and $\mathrm{Cl}^{-}$), and minerals (sum of $\mathrm{K}^{+}, \mathrm{Ca}^{++}$, and $\mathrm{Mg}^{++}$). Vertical profile plots for the individual species are shown in Figure 5. In addition, estimated POM (EPOM) levels and total particle soluble mass are also listed in the table. As noted in the experiment section, there was no POM measurement on board NASA DC-8 during INTEX-NA. Because the published ICARTT results indicate that POM is an important (and often dominant) aerosol chemical component in this region [e.g., Peltier et al., 2007; Clarke et al., 
Table 2a. Summary of UNH Filter Measurement of Aerosol Chemical Compositions

\begin{tabular}{|c|c|c|c|c|c|c|c|c|}
\hline Alt & $\begin{array}{c}\text { Air } \\
\text { Mass } \\
\end{array}$ & $\begin{array}{l}\mathrm{SO}_{4}^{=} \mu \mathrm{g} \\
\mathrm{std} \mathrm{m}^{-3} \\
\end{array}$ & $\begin{array}{l}\mathrm{NO}_{3}^{-} \mu \mathrm{g} \\
\mathrm{std} \mathrm{m}^{-3} \\
\end{array}$ & $\begin{array}{l}\mathrm{NH}_{4}^{+} \mu \mathrm{g} \\
\text { std m}^{-3}\end{array}$ & $\begin{array}{c}\text { Sea Salt } \\
\mu \mathrm{g} \mathrm{std} \mathrm{m}^{-3} \\
\end{array}$ & $\begin{array}{c}\text { Minerals }^{\mathrm{b}} \\
\mu \mathrm{g} \mathrm{std} \mathrm{m}^{-3}\end{array}$ & $\begin{array}{c}\mathrm{EPOM}^{\mathrm{c}} \\
\mu \mathrm{g} \mathrm{std} \mathrm{m}^{-3} \\
\end{array}$ & $\begin{array}{c}\text { Total } \\
\mu \mathrm{g} \mathrm{std} \mathrm{m}^{-3} \\
\end{array}$ \\
\hline \multirow[t]{5}{*}{$0-2 \mathrm{~km}$} & $\mathrm{EC}$ & $5.1 \pm 2.8$ & $0.23 \pm 0.15$ & $0.99 \pm 0.53$ & $0.16 \pm 0.15$ & $0.18 \pm 0.12$ & $9.6 \pm 5.2$ & $16.3 \pm 5.9$ \\
\hline & CA & $0.73 \pm 0.70$ & $0.17 \pm 0.17$ & $0.17 \pm 0.11$ & $0.39 \pm 0.56$ & $0.15 \pm 0.13$ & $2.1 \pm 2.0$ & $3.7 \pm 2.2$ \\
\hline & $\mathrm{AO}$ & $1.0 \pm 0.94$ & $0.20 \pm 0.15$ & $0.18 \pm 0.19$ & $1.16 \pm 1.12$ & $0.15 \pm 0.11$ & $0.44 \pm 0.38$ & $3.1 \pm 1.5$ \\
\hline & WCP & & & & & & & \\
\hline & all data & $2.57 \pm 2.70$ & $0.24 \pm 0.22$ & $0.51 \pm 0.51$ & $0.42 \pm 0.60$ & $0.15 \pm 0.12$ & $6.6 \pm 6.8$ & $10.5 \pm 7.4$ \\
\hline \multirow[t]{5}{*}{$2-4 \mathrm{~km}$} & $\mathrm{EC}$ & $2.39 \pm 2.47$ & $0.35 \pm 0.52$ & $0.49 \pm 0.40$ & $0.12 \pm 0.14$ & $0.08 \pm 0.05$ & $1.8 \pm 1.7$ & $5.2 \pm 3.1$ \\
\hline & CA & $0.77 \pm 0.79$ & $0.30 \pm 0.66$ & $0.34 \pm 0.52$ & $0.15 \pm 0.21$ & $0.17 \pm 0.22$ & $0.90 \pm 0.73$ & $2.6 \pm 1.4$ \\
\hline & $\mathrm{AO}$ & & & & & & & \\
\hline & WCP & & & & & & & \\
\hline & all data & $1.7 \pm 2.0$ & $0.35 \pm 0.59$ & $0.44 \pm 0.46$ & $0.14 \pm 0.18$ & $0.13 \pm 0.17$ & $1.4 \pm 1.5$ & $4.0 \pm 2.6$ \\
\hline \multirow[t]{5}{*}{$4-10 \mathrm{~km}$} & $\mathrm{EC}$ & $0.22 \pm 0.16$ & $0.03 \pm 0.03$ & $0.03 \pm 0.02$ & $0.12 \pm 0.14$ & $0.05 \pm 0.04$ & $0.10 \pm 0.06$ & $0.55 \pm 0.23$ \\
\hline & CA & $0.44 \pm 0.31$ & $0.11 \pm 0.17$ & $0.15 \pm 0.16$ & $0.09 \pm 0.1$ & $0.11 \pm 0.19$ & $0.26 \pm 0.13$ & $1.2 \pm 0.5$ \\
\hline & $\mathrm{AO}$ & & & & & & & \\
\hline & WCP & $0.34 \pm 0.31$ & $0.14 \pm 0.38$ & $0.06 \pm 0.04$ & $0.08 \pm 0.1$ & $0.10 \pm 0.20$ & $0.16 \pm 0.13$ & $0.88 \pm 0.56$ \\
\hline & all data & $0.35 \pm 0.32$ & $0.11 \pm 0.39$ & $0.09 \pm 0.2$ & $0.09 \pm 0.1$ & $0.06 \pm 0.10$ & $0.18 \pm 0.13$ & $0.88 \pm 0.58$ \\
\hline
\end{tabular}

${ }^{\mathrm{a}} \mathrm{Sum}$ of $\mathrm{Cl}^{-}$and $\mathrm{Na}^{+}$.

${ }^{\mathrm{b}} \mathrm{Sum}$ of $\mathrm{K}^{+}, \mathrm{Ca}^{++}$, and $\mathrm{Mg}^{++}$

${ }^{\mathrm{c}}$ Estimated of particulate organic matter. EPOM was derived from the average $\mathrm{SO}_{4}^{=}$concentration for each air mass and altitude bin, using the ratio of POM to the sum of POM and $\mathrm{SO}_{4}^{=}$(F0) reported by Quinn et al. [2006] (section 3.2).

2007; Quinn et al., 2006; de Gouw et al., 2005], we believe it is necessary to estimate the possible contribution of organic species to the overall mass loading in each of the air mass types. The EPOM values given in the table were derived from the average $\mathrm{SO}_{4}^{=}$concentration for each air mass and altitude bin, using the ratio of POM to the sum of POM and $\mathrm{SO}_{4}^{=}\left(\mathrm{F}_{\mathrm{o}}\right)$ reported by Quinn et al. [2006]. These investigators summarized the $\mathrm{F}_{\mathrm{o}}$ values according to the aerosol age, which can be estimated by the $\mathrm{SO}_{4}^{=}$to $\mathrm{SO}_{4}^{=}+$ $\mathrm{SO}_{2}$ partition ratio, $\mathrm{F}_{\mathrm{SO} 4}$. The values of $\mathrm{F}_{\mathrm{o}}$ used in this study were estimated by interpolating the results given in Table 1 of Quinn et al. [2006] using the $\mathrm{F}_{\mathrm{SO} 4}$ values estimated for each of the cases listed in Table $2 \mathrm{~b}$. The uncertainties given in the table are a simple propagation of the $\mathrm{SO}_{4}^{=}$standard deviation.

[31] To evaluate the values of the EPOM, we also estimated POM from the difference in mass derived from total aerosol volume (assuming mass densities for inorganic, mostly ammonium sulfate and bisulfate, and organic aerosol components of 1.78 and $1.2 \mathrm{~g} \mathrm{~cm}^{-3}$, respectively) and the sum of the measured soluble ion masses. The assumed densities are consistent with those used by Peltier et al. [2007] and are based on the work by [Turpin and Lim, 2001]. The resulting POM values from this approach are generally lower than the values shown in Table $2 \mathrm{a}$, but within a factor of 2.5. In addition, we also assessed the EPOM values using the empirical equations based on $\mathrm{CO}$ or isopropyl nitrate [e.g., Sullivan et al., 2006; de Gouw et al., 2005]. The equations are mostly derived from heavily polluted regions or plumes. The EC $0-2 \mathrm{~km}$ represents the most polluted case in this study. For this air mass, there is a reasonable correlation between $\mathrm{SO}_{4}^{=}$and isopropyl nitrate with an $\mathrm{R}^{2}$ value of 0.43 . The POM value estimated from isopropyl nitrate using the relation described by de Gouw et al. [2005] is about a factor of 2 lower than the value given in Table $2 \mathrm{a}$, but the $\mathrm{CO}$ equation would give a value about a factor of 1.5 high. Overall, we believe the EPOM are reasonable for this study in absence of the actual observations and assign a systematic uncertainty of a factor 2.5 .
[32] Consistent with the plots of Figure 5, the total estimated aerosol mass given in Table 2a shows a sharp vertical gradient. For all data, the $2-4$ altitude regime is about a factor of 2.5 lower than the $0-2 \mathrm{~km}$ layer but over a factor of 4 higher than the $4-10 \mathrm{~km}$ regime. From $0-2 \mathrm{~km}$ to $4-10 \mathrm{~km}$, the aerosol mass dropped by more than one order of magnitude. The EC air mass exhibits the largest gradient, with values decreasing from 16.3 to $0.55 \mu \mathrm{g}$ std $\mathrm{m}^{-3}$, or about a factor of 30 , in going from the lowest to highest altitude bins. In contrast, aerosol mass loadings in the CA air mass only decreased from 3.7 to $1.2 \mu \mathrm{g} \mathrm{std}^{-3}$, or a factor of 3 , between the lower and upper troposphere.

[33] For the 0-2 km altitude range, EPOM and $\mathrm{SO}_{4}^{=}$ aerosols accounted for 59 and $31 \%$ of the total mass loading, respectively, in EC air masses. The POM mass fraction is generally consistent with the values reported by Quinn et al. [2006] and Quinn and Bates [2003] based on shipboard measurements of submicron particles in the coast

Table 2b. Summary of Molar Equivalence Ratio and Partition Ratio of Sulfur and N(IV) Species

\begin{tabular}{|c|c|c|c|c|c|}
\hline Alt & $\begin{array}{c}\text { Air } \\
\text { Mass }\end{array}$ & $\mathrm{ER}^{\mathrm{a}}$ & ER $_{\text {TOTAL }}{ }^{b}$ & $\mathrm{FSO}_{4}^{=} \mathrm{c}$ & $\mathrm{FNO}_{3}^{-} \mathrm{c}$ \\
\hline $0-2$ & $\mathrm{EC}$ & $0.52 \pm 0.13$ & $0.61 \pm 0.15$ & $0.49 \pm 0.14$ & $0.07 \pm 0.04$ \\
\hline \multirow[t]{4}{*}{$\mathrm{km}$} & $\mathrm{CA}$ & $0.69 \pm 0.33$ & $1.12 \pm 0.46$ & $0.36 \pm 0.22$ & $0.10 \pm 0.09$ \\
\hline & $\mathrm{AO}$ & $0.45 \pm 0.20$ & $0.99 \pm 0.47$ & $0.21 \pm 0.17$ & $0.26 \pm 0.13$ \\
\hline & WC & & & & \\
\hline & all data & $0.56 \pm 0.25$ & $0.85 \pm 0.41$ & $0.39 \pm 0.21$ & $0.14 \pm 0.11$ \\
\hline $2-4$ & $\mathrm{EC}$ & $0.56 \pm 0.23$ & $0.62 \pm 0.25$ & $0.9 \pm 0.06$ & $0.11 \pm 0.10$ \\
\hline \multirow[t]{4}{*}{$\mathrm{km}$} & $\mathrm{CA}$ & $1.2 \pm 0.7$ & $1.9 \pm 1.7$ & $0.75 \pm 0.18$ & $0.16 \pm 0.19$ \\
\hline & $\mathrm{AO}$ & & & & \\
\hline & WC & & & & \\
\hline & all data & $0.92 \pm 0.62$ & $1.3 \pm 1.4$ & $0.83 \pm 0.14$ & $0.14 \pm 0.15$ \\
\hline $4-10$ & $\mathrm{EC}$ & $0.54 \pm 0.37$ & $0.96 \pm 0.87$ & $0.47 \pm 0.17$ & $0.09 \pm 0.04$ \\
\hline \multirow[t]{4}{*}{$\mathrm{km}$} & $\mathrm{CA}$ & $0.77 \pm 0.35$ & $1.0 \pm 0.6$ & $0.76 \pm 0.15$ & $0.27 \pm 0.19$ \\
\hline & $\mathrm{AO}$ & & & & \\
\hline & WC & $0.57 \pm 0.36$ & $1.0 \pm 1.0$ & $0.70 \pm 0.18$ & $0.13 \pm 0.15$ \\
\hline & all data & $0.57 \pm 0.34$ & $0.92 \pm 0.79$ & $0.67 \pm 0.17$ & $0.12 \pm 0.14$ \\
\hline
\end{tabular}

${ }^{\mathrm{a}} \mathrm{ER}$ is the molar equivalence ratio of $\mathrm{SO} 4=, \mathrm{NO} 3-$, and $\mathrm{NH} 4+$, as defined by Quinn et al. [2006].

${ }^{\mathrm{b}}$ ERtotal is the molar equivalence ratio for al inorganic water-solution cations and anions.

${ }^{\mathrm{c}} \mathrm{FSO}_{4}^{=}$and $\mathrm{FNO}_{3}^{-}$are the fractions of total $\mathrm{S}(\mathrm{VI})$ and $\mathrm{N}(\mathrm{V})$ present as sulfate and nitrate aerosols. 
regions of NE US. Similarly, CA air masses contained 58\% and $19 \%$ of EPOM and $\mathrm{SO}_{4}^{-}$, but exhibited $\mathrm{NO}_{3}^{-}$and mineral mass fractions that were about 4 times higher than the EC source region. In general, these aerosol chemical composition characteristics are consistent with the influence of urban/industrial emissions. For the $\mathrm{AO}$ air mass, the two largest components were sea-salt and $\mathrm{SO}_{4}^{=}$, which accounted for $37 \%$ and $32 \%$, respectively, of the total mass loading; EPOM only contributed about $14 \%$ of the total mass in this air mass type. For the entire data set, EPOM and $\mathrm{SO}_{4}^{=}$ accounted for over $87 \%$ of the total aerosol mass loading.

[34] Because of its proximity to surface sources, the 0 $2 \mathrm{~km}$ altitude bin typically bore the strongest emission signatures. A correlation analysis of data recorded in this height range reveals that both $\mathrm{SO}_{4}^{=}$and $\mathrm{NH}_{4}^{+}$exhibited significantly positive correlations with $\mathrm{CO}$ and isopropyl nitrate for the EC air mass case as well as the overall data set. Focusing specifically on the relationship between the aerosol components and isopropyl nitrate, the $\mathrm{R}^{2}$ value for $\mathrm{SO}_{4}^{=}$is 0.66 and 0.43 for all data and $\mathrm{EC}$ air mass, respectively. For $\mathrm{NH}_{4}^{+}$, the $\mathrm{R}^{2}$ values are 0.75 for the overall data set and 0.56 for EC. The difference between composite data set and EC grouping reflects that the overall data set has larger ranges of variations. As discussed earlier, isopropyl nitrate is a product of anthropogenic hydrocarbon oxidation and is often found to have significant correlation with POM [e.g., de Gouw et al., 2005; Quinn et al., 2006; Sullivan et al., 2006; Peltier et al., 2007]. The significant correlation suggests that the aerosol $\mathrm{SO}_{4}^{=}$and $\mathrm{NH}_{4}^{+}$content are primarily anthropogenic in origin. Aerosol nitrate concentrations within EC air masses were also correlated with isopropyl nitrate $\left(\mathrm{R}^{2}=\right.$ 0.49 ), but there was no discernable relationship between aerosol nitrate and $\mathrm{CO}$, isopropyl nitrate, $\mathrm{HNO}_{3}$, or $\mathrm{NO}_{2}$ for the overall data set or any of the other air mass types. This suggests that anthropogenic emissions had a significant impact on the EC nitrate composition but there are other unidentified processes controlling the nitrate abundance for the rest of the cases.

[35] Within the middle altitude regime, i.e., $2-4 \mathrm{~km}$, EPOM and $\mathrm{SO}_{4}^{=}$were the dominant components of aerosol mass for the $\mathrm{EC}$ grouping, but $\mathrm{SO}_{4}^{=}$made the larger contribution at $46 \%$ versus $36 \%$ for EPOM. In addition, the mass fraction of $\mathrm{NO}_{3}^{-}$is increased by about a factor of 5 from the lower altitudes, i.e., 1.4 versus $6.7 \%$. For the CA air mass, the mass fractions for $\mathrm{NO}_{3}^{-}$and $\mathrm{NH}_{4}^{+}$(at $11 \%$ and $13 \%$, respectively) are about a factor of 2.5 higher than the values for $0-2 \mathrm{~km}$. Similar to the lower altitude case, the EPOM is still the largest component, accounting for $34 \%$. Sulfate is the close second largest component contributing $29 \%$ of the total. The EPOM and $\mathrm{NH}_{4}^{+}$enhancements within the CA reflect the influence of the biomass burning emissions within this height regime.

[36] For the 4-10 km altitude range, EPOM is a significant component of the aerosol mass, accounting for $\sim 20 \%$ of the total for the overall data set, but $\mathrm{SO}_{4}^{=}$is the largest component, accounting for $37-40 \%$ of the total. The CA air mass had the largest $\mathrm{NH}_{4}^{+}$mass fraction, whereas WC air mass had the highest nitrate mass fraction. WCP air also contained numerous layers that were enhanced in mineral dust tracers, probably as a result of convective input over the central portion of the continent. Since the number of the filter samples is limited in this altitude regime, it is difficult to narrow down the potential sources which lead to the aerosol chemical composition characteristics.

[37] Table $2 \mathrm{~b}$ shows several parameters derived from the aerosol chemical composition measurements. The parameter ER is the molar equivalence ratio of $\mathrm{SO}_{4}^{=}, \mathrm{NO}_{3}^{-}$, and $\mathrm{NH}_{4}^{+}$, and is defined by Quinn et al. [2006] as:

$$
\mathrm{ER}=\mathrm{m}\left(\mathrm{NH}_{4}^{+}\right) /\left(2 \mathrm{~m}\left(\mathrm{SO}_{4}^{-}\right)+\mathrm{m}\left(\mathrm{NO}_{3}^{-}\right)\right)
$$

[38] Where $\mathrm{m}\left(\mathrm{NH}_{4}^{+}\right),\left(\mathrm{m}\left(\mathrm{SO}_{4}^{\overline{-}}\right)\right.$ and $\mathrm{m}\left(\mathrm{NO}_{3}^{-}\right)$are molar concentrations in $\mu \mathrm{mol} \mathrm{m}^{-3}$. Similarly, $\mathrm{ER}_{\text {TOTAL }}$ is defined as the molar equivalence ratio for all inorganic watersolution cations and anions:

$$
\begin{aligned}
\mathrm{ER}_{\mathrm{TOTAL}}= & \left(\mathrm{m}\left(\mathrm{NH}_{4}^{+}\right)+\mathrm{m}\left(\mathrm{Na}^{+}\right)+\mathrm{m}\left(\mathrm{K}^{+}\right)+2 \mathrm{~m}\left(\mathrm{Ca}^{++}\right)\right. \\
& \left.+2 \mathrm{~m}\left(\mathrm{Mg}^{++}\right)\right) /\left(2 \mathrm{~m}\left(\mathrm{SO}_{4}^{-}\right)+\mathrm{m}\left(\mathrm{NO}_{3}^{-}\right)+\mathrm{m}\left(\mathrm{Cl}^{-}\right)\right)
\end{aligned}
$$

[39] Again, all ion concentrations are in $\mu \mathrm{mol} \mathrm{m}{ }^{-3}$. Both ER and ER $\mathrm{EROTAL}_{\text {can }}$ be viewed as an indicator of the aerosol acidity, with an implicit assumption that the watersoluble organics are neutral. Table $2 b$ shows that, except for the $2-4 \mathrm{~km}$ altitude range within CA air masses, ER values were significantly below unity for all cases. The greater neutrality of the CA mid-altitude case reflects the influence of enhanced $\mathrm{NH}_{4}^{+}$and $\mathrm{K}^{+}$levels associated with forest fire emissions. Interestingly, $\mathrm{ER}_{\text {TOTAL }}$ values suggest that a majority of the aerosol populations were close to neutral for most of the air mass types and altitude regimes. Notable exceptions were EC air mass, which was strongly acidic in the 0 and $4 \mathrm{~km}$ altitude range, and the CA air mass, which was strongly alkaline between 2 and $4 \mathrm{~km}$. The regression slope between $\mathrm{EC} \mathrm{SO}_{4}^{=}$and $\mathrm{NH}_{4}^{+}$is slightly $>1$, suggesting that the EC aerosol is primarily composed of ammonium bisulfate. Comparing Tables $2 \mathrm{a}$ and $2 \mathrm{~b}$, it is interesting to see that there are measurable amounts of $\mathrm{NO}_{3}^{-}$in all cases, regardless of the $\mathrm{ER}_{\mathrm{TOTAL}}$ values. This cannot be explained by the conventional theory, if the aerosols are assumed to be internal mixtures. Given the long integration times of the filter sampling, however, we suspect that most samples included external mixtures of particles, including some coarse particle nitrate associated with sea-salt and/or dust. At the same time, we note that within any given altitude range, the $\mathrm{NO}_{3}^{-}$mass fraction is always higher for the cases that are neutral or alkaline than the acidic ones. Potentially, this issue can be resolved by one or a combination of the possibilities: existence of water-soluble organic sulfate, missing anion species in the filter measurement, or $\mathrm{NO}_{3}^{-}$ measurement artifacts. From single particle composition measurements recorded aboard the NOAA aircraft during ICARTT, Murphy et al. [2006] reported that organic sulfates were present within many of the sampled air masses, however, it is unclear whether these compounds are water soluble.

[40] Also shown on Table $2 \mathrm{~b}$ are the fractions of total $\mathrm{S}(\mathrm{VI})$ and $\mathrm{N}(\mathrm{V})$ present as sulfate and nitrate aerosols. From shipboard measurements recorded over the Gulf of Maine during ICARTT, Quinn et al. [2006] found values for sulfate fraction, $\mathrm{F}_{\mathrm{SO} 4}$, that ranged from 0.04 in samples 
collected in Boston Harbor, to near 1 in parcels intercepted several days downwind of source regions. In this study, low to mid level EC air masses exhibited the highest $\mathrm{F}_{\mathrm{SO} 4}$ values, even though they were typically less aged than the other air mass groupings. We speculate that the high humidities and peroxide concentrations associated with the EC air masses enhanced rates of heterogeneous oxidation and resulted in shorter $\mathrm{SO}_{2}$ lifetimes; it is also possible that cloud processing had removed a portion of the sulfate aerosols from the more aged air masses. The relatively low $\mathrm{F}_{\mathrm{SO} 4}$ values seen in aged $\mathrm{AO}$ cases support our above contention that the $\mathrm{SO}_{2}$ enhancements seen in these air masses were related to the recent input of ship emissions. $\mathrm{FNO}_{3}$ values also vary with air mass age, but appear to be driven primarily by gas phase $\mathrm{HNO}_{3}$ concentrations.

\section{Summary and Conclusions}

[41] Air in the western Atlantic, off the northeast coast of the United States, was sampled during the summer of 2004 by the NASA DC- 8 during the INTEX-NA campaign. We observed aerosols and trace gases in a study area that is defined by a parallelogram adjacent to the northeastern coastline of the United States. Using the FSU back trajectory data and the UNH merge from the INTEX-NA archive, we found that air mass composition was influenced by transport from four primary sources: short range transport from the Atlantic Ocean and the East Coast and longer range transport from the West Coast/Pacific and Canadian/ Alaskan. Air masses originally over the East Coast and Canada/Alaska exhibited significant enhancements in aerosol concentrations and optical parameters due to urban/ industrial emissions and some influence from wild fires in northwestern Canada and Alaska, respectively. These trajectory-based air mass classifications are generally supported by the analysis of gas phase tracer distributions.

[42] The observed aerosol mass and volume loading showed sharp vertical gradients. The largest vertical decrease was found in the EC air mass, where total volume dropped by a factor of $\sim 20$ between the surface and $9 \mathrm{~km}$ and the total mass (including EPOM) declined by a factor of 30 between the $0-2 \mathrm{~km}$ to $4-10 \mathrm{~km}$ altitude bins. Not surprisingly, aerosol scattering and absorption coefficients were the highest within the polluted boundary layer $(0-2 \mathrm{~km})$ of EC air masses. Except in cases where forest fire plumes were encountered, aerosol extinction with the 4 to $10 \mathrm{~km}$ range of all air masses made a negligible contribution to column optical depth. The WCP and CA air masses contained ECCN concentrations of $4-7 \mathrm{~cm}^{-3}$ in the 4 to $10 \mathrm{~km}$ altitude range, and thus exhibited the greatest potential for influencing cloud processes in downwind regions

[43] In the lowest altitude bin $(0-2 \mathrm{~km}), \mathrm{EC}$ air mass exhibited the highest total mass concentration, with EPOM and $\mathrm{SO}_{4}^{=}$the dominant components (i.e., $90 \%$ of the total). The CA air mass had significantly lower concentrations, but was also dominated by EPOM and $\mathrm{SO}_{4}^{=}$. These characteristics are consistent with strong influence from urban/ industrial pollutions and/or biomass burning. By contrast, the largest component for AO air mass is sea-salt, as expected, and followed by $\mathrm{SO}_{4}^{=}$. At the mid altitude regime, i.e., 2-4 km, both $\mathrm{EC}$ and $\mathrm{CA}$ air masses are more aged than those sampled in lower altitude regime. The EC air mass also contained the largest aerosol mass concentrations, with $\mathrm{SO}_{4}^{=}$and EPOM accounting for $46 \%$ and $35 \%$, respectively, of the total. In CA air mass, EPOM remains to be the largest component, followed by $\mathrm{SO}_{4}^{=}$. The fractional contributions of $\mathrm{NH}_{4}^{+}$and $\mathrm{NO}_{3}^{-}$to total mass are significantly higher than at the lowest altitudes. This is consistent with biomass burning influence on CA air mass. For the $4-10 \mathrm{~km}$ altitude range, the WCP air mass has the highest mass fraction of $\mathrm{NO}_{3}^{-}$and minerals, which is consistent with input from convective systems over the mid-section of the continent. An aerosol charge balance analysis suggests that, except in cases of recent anthropogenic input, aerosols within each of the air masses were generally neutral. However, the observed $\mathrm{NH}_{4}^{+}$levels could balance only $45-70 \%$ the charges carried by $\mathrm{SO}_{4}^{=}$and $\mathrm{NO}_{3}^{-}$for most of the studied cases.

[44] Acknowledgments. The work was supported by the NASA Tropospheric Chemistry Program and Atmospheric Chemistry Modeling and Analysis Program. The authors would like to thank the DC-8 crew and the INTEX-NA science team for making this work possible. The authors would also like to express their sincere appreciation to Drs. Dan Murphy, Patricia Quinn, Chuck Brock, and Rodney Weber for their insightful discussions and comments.

\section{References}

Albrecht, B. A. (1989), Aerosols, cloud microphysics, and fractional cloudiness, Science, 245, 1227-1230.

Anderson, T., and J. Ogren (1998), Determining aerosol radiative properties using a TSI 3563 integrating nephelometer, Aerosol Sci. Technol., 29, $57-69$.

Anderson, T. L., et al. (1996), Performance characteristics of a high-sensitivity, three wavelength, total scatter/backscatter nephelometers, J. Atmos. Oceanic Technol., 13, 967-986.

Bertram, T. H., et al. (2007), Direct measurements of the convective recycling of the upper troposphere, Science, 315(5813), 816-820.

Blake, N., et al. (2003), NMHCs and halocarbons in Asian continental outflow during the Transport and Chemical Evolution over the Pacific (TRACE-P) field campaign: Comparison with PEM-West B, J. Geophys. Res., 108(D20), 8806, doi:10.1029/2002JD003367.

Bond, T., and Robert W. Bergstrom (2006), Light absorption by carbonaceous particles: An investigative review, Aerosol Sci. Technol., 40, $27-67$.

Bond, C. T., T. L. Anderson, and D. Campbell (1999), Calibration and intercomparison of filter-based measurements of visible light absorption by aerosols, Aerosol Sci. Technol., 30, 582-600.

Charlson, R. J., et al. (1987), Oceanic phytoplankton, atmospheric sulphur, cloud albedo and climate, Nature, 326, 655-661.

Chen, G., et al. (2005), An investigation of the chemistry of ship emission plumes during ITCT 2002, J. Geophys. Res., 110, D10S90, doi:10.1029/ 2004JD005236.

Chen, M., R. Talbot, H. Mao, B. Sive, J. Chen, and R. J. Griffin (2007), Air mass classification in coastal New England and its relationship to meteorological conditions, J. Geophys. Res., 112, D10S05, doi:10.1029/ 2006JD007687.

Clarke, A. D. (1991), A thermo-optic technique for in situ analysis of size resolved aerosol physicochemistry, Atmos. Environ., 25, 635-644.

Clarke, A. D., et al. (2004), Size distributions and mixtures of dust and black carbon aerosol in Asian outflow: Physiochemistry and optical properties, J. Geophys. Res., 109, D15S09, doi:10.1029/2003JD004378.

Clarke, A. D., et al. (2007), Biomass burning and pollution aerosol over North America: Organic components and their influence on spectral optical properties and humidification response, J. Geophys. Res., 112, D12S18, doi:10.1029/2006JD007777.

de Gouw, J. A., et al. (2005), Budget of organic carbon in a polluted atmosphere: Results from the New England air quality study in 2002 , J. Geophys. Res., 110(D16), D16305, doi:10.1029/2004JD005623.

Dibb, J. E., R. W. Talbot, E. M. Scheuer, D. R. Blake, N. J. Blake, G. L. Gregory, G. W. Sachse, and D. C. Thornton (1999), Aerosol chemical composition and distribution during the Pacific Exploratory Mission, Tropics, J. Geophys. Res., 104, 5785-5800.

Dibb, J. E., R. W. Talbot, and E. M. Scheuer (2000), Composition and distribution of aerosols over the North Atlantic during the Subsonic 
Assessment Ozone and Nitrogen Oxide Experiment (SONEX), J. Geophys. Res., 105, 3709-3717.

Dibb, J. E., R. W. Talbot, G. Seid, C. Jordan, E. Scheuer, E. Atlas, N. J. Blake, and D. R. Blake (2003a), Airborne sampling of aerosol particles: Comparison between surface sampling at Christmas Island and P-3 sampling during PEM Tropics B, J. Geophys. Res., 107, 8230, doi:10.1029/2001JD000408. [printed 108(D2), 2003]

Dibb, J. E., R. W. Talbot, E. Scheuer, G. Seid, M. Avery, and H. Singh (2003b), Aerosol chemical composition in Asian continental outflow during the Transport and Chemical Evolution Over the Pacific (TRACE-P): Comparison with PEM-West B, J. Geophys. Res., 108(D21), 8815, doi:10.1029/2002JD003111.

Fehsenfeld, F. C., M. Trainer, D. D. Parrish, A. V. Volz-Thomas, and S. Penkett (1996), North Atlantic Regional Experiment 1993 summer intensive: Foreword, J. Geophys. Res., 101(D22), 28,869-28,876, doi:10.1029/96JD03629.

Fehsenfeld, F. C., et al. (2006), International Consortium for Atmospheric Research on Transport and Transformation (ICARTT): North America to Europe-Overview of the 2004 summer field study, J. Geophys. Res., 111, D23S01, doi:10.1029/2006JD007829.

Fuelberg, H. E., Jr., M. V. Watson, M. C. Sinha, K. E. Pickering, A. M. Thompson, G. W. Sachse, D. R. Blake, and M. R. Schoeberl (1996), TRACE A trajectory intercomparison. 2. Isentropic and kinematic methods, J. Geophys. Res., 101(D19), 23,927-23,940, doi:10.1029/ 96JD02122.

Fuelberg, H. E., J. R. Hannan, P. F. J. van Velthoven, E. V. Browell, G. Bieberbach Jr., R. D. Knabb, G. L. Gregory, K. E. Pickering, and H. B. Selkirk (2000), A meteorological overview of the SONEX period, J. Geophys. Res., 105, 3633-3651.

Fuelberg, H. E., M. J. Porter, C. M. Kiley, J. J. Halland, and D. Morse (2007), Meteorological conditions and anomalies during the Intercontinental Chemical Transport Experiment-North America, J. Geophys. Res., 112, D12S06, doi:10.1029/2006JD007734.

Galloway, J. N., and D. M. Whelpdale (1987), WATOX-86 over-view and western North Atlantic Ocean S and N atmospheric budgets, Global Biogeochem. Cycles, 1, 261-281.

Hennigan, C. J., S. T. Sandholm, S. Kim, R. E. Stickel, L. G. Huey, and R. J. Weber (2006), Influence of Ohio River valley emissions on fine particulate sulfate measured from aircraft over large regions of the eastern United States and Canada during INTEX-NA, J. Geophys Res., 111, D24S04, doi:10.1029/2006JD007282.

Huey, L. G., et al. (2004), CIMS measurements of $\mathrm{HNO}_{3}$ and $\mathrm{SO}_{2}$ at the South Pole during ISCAT 2000, Atmos. Environ., 38(32), 5411-5421.

Kim, S., et al. (2007), Measurement of $\mathrm{HO}_{2} \mathrm{NO}_{2}$ in the free troposphere during the Intercontinental Chemical Transport Experiment-North America 2004, J. Geophys. Res., 112, D12S01, doi:10.1029/ 2006JD007676

Liang, Q., et al. (2007), Summertime influence of Asian pollution in the free troposphere over North America, J. Geophys. Res., 112, D12S11, doi:10.1029/2006JD007919.

McNaughton, C., et al. (2007), Results from the DC-8 Inlet Characterization Experiment (DICE): Airborne versus surface sampling of mineral dust and sea salt aerosols, Aerosol Sci. Technol., 41, 136-159.

Murphy, D. M., D. J. Cziczo, K. D. Froyd, P. K. Hudson, B. M. Matthew, A. M. Middlebrook, R. E. Peltier, A. Sullivan, D. S. Thomson, and R. J. Weber (2006), Single-particle mass spectrometry of tropospheric aerosol particles, J. Geophys. Res., 111, D23S32, doi:10.1029/ 2006JD007340.

Peltier, R. E., A. P. Sullivan, R. J. Weber, C. A. Brock, A. G. Wollny, J. S. Holloway, J. A. de Gouw, and C. Warneke (2007), Fine aeroso bulk composition measured on WP-3D research aircraft in vicinity of the Northeastern United States-Results from NEAQS, Atmos. Chem. Phys., 7, 3231-3247.

Pruppacher, H. R., and J. D. Klett (1997), Microphysics of clouds and precipitation, 2nd ed., Kluwer Academic Publishers, Boston, MA.

Quinn, P. K., and T. S. Bates (2003), North American, Asian, and Indian haze: Similar regional impacts on climate?, Geophys. Res. Lett., 30(11), 1555, doi:10.1029/2003GL016934.
Quinn, P. K., et al. (2006), Impacts of sources and aging on submicrometer aerosol properties in the marine boundary layer across the Gulf of Maine, J. Geophys. Res., 111, D23S36, doi:10.1029/2006JD007582.

Russell, P. B., P. V. Hobbs, and L. L. Stowe (1999), Aerosol properties and radiative effects in the United States East Coast haze plume: An overview of the Tropospheric Aerosol Radiative Forcing Observational Experiment (TARFOX), J. Geophys. Res., 104(D2), 2213-2222.

Russo, R., et al. (2003), Chemical composition of Asian continental outflow over the western Pacific: Results from Transport and Chemical Evolution over the Pacific (TRACE-P), J. Geophys. Res., 108(D20), 8804, doi:10.1029/2002JD003184.

Sachse, G. W., G. F. Hill, E. P. Condon, and R. A. Rasmussen (1987), Airborne intercomparison of carbon monoxide measurement techniques, J. Geophys. Res., 92(2), 2009-2019.

Schuster, G. L., O. Dubovik, B. N. Holben, and E. E. Clothiaux (2005), Inferring black carbon content and specific absorption from Aerosol Robotic Network (AERONET) aerosol retrievals, J. Geophys. Res., 110, D10S17, doi:10.1029/2004JD004548.

Shinozuka, Y., A. D. Clarke, S. G. Howell, V. N. Kapustin, C. S. McNaughton, J. Zhou, and B. E. Anderson (2007), Aircraft profiles of aerosol microphysics and optical properties over North America: Aerosol optical depth and its association with PM2.5 and water uptake, J. Geophys. Res., 112, D12S20, doi:10.1029/2006JD007918.

Singh, H, et al. (2003), In situ measurements of $\mathrm{HCN}$ and $\mathrm{CH} 3 \mathrm{CN}$ over the Pacific Ocean: Sources, sinks, and budgets, J. Geophys. Res., 108(D20), 8795, doi:10.1029/2002JD003006.

Singh, H. B., W. H. Brune, J. H. Crawford, D. J. Jacob, and P. B. Russell (2006), Overview of the summer 2004 Intercontinental Chemical Transport Experiment-North America (INTEX-A), J. Geophys. Res., 111, D24S01, doi:10.1029/2006JD007905.

Stohl, A. (1998), Computation, accuracy, and applications of trajectoriesA review and bibliography, Atmos. Environ., 32, 947-966.

Stohl, A. (Ed.) (2004), Intercontinental transport of air pollution, in The Handbook of Environmental Chemistry, p. 320, Springer-Verlag, Berlin.

Stohl, A., G. Wotana, P. Seibert, and H. Kromp-Kolb (1995), Interpolation errors in wind fields as a function of spatial and temporal resolution and their impact on different types of kinematic trajectories, J. Appl. Meteorol., $34,2149-2165$

Sullivan, A. P., R. E. Peltier, C. A. Brock, J. A. de Gouw, J. S. Holloway, C. Warneke, A. G. Wollny, and R. J. Weber (2006), Airborne measurements of carbonaceous aerosol soluble in water over northeastern United States: Method development and an investigation into water soluble organic carbon sources, J. Geophys. Res., 111, D05314, doi:10.1029/ 2005JD006485.

Talbot, R. W., et al. (1999), Reactive nitrogen budget during the NASA SONEX mission, Geophys. Res. Lett., 26, 3057-3060.

Talbot, R., et al. (2003), Reactive nitrogen in Asian continental outflow over the western Pacific: Results from the NASA TRACE-P airborne mission, J. Geophys. Res., 108(D20), 8803, doi:10.1029/2002JD003129.

Turpin, B. J., and H. J. Lim (2001), Species contributions to PM2.5 mass concentrations: Revisiting common assumptions for estimating organic mass, Aerosol Sci. Technol., 35(1), 602-610.

Twomey, S. A. (1977), The effect of cloud scattering on the absorption of solar radiation by atmospheric dust, J. Atmos. Sci., 29, 1156-1159.

B. E. Anderson, G. Chen, A. Omar, G. Sachse, and G. Schuster, NASA Langley Research Center, Hampton, VA, USA. (bruce.e.anderson@nasa. gov)

D. Blake, Department of Chemistry, University of California, Irvine, CA USA. (dblake@orion.oac.uci.edu)

A. Clarke and C. McNaughton, School of Ocean and Earth Science and Technology, University of Hawaii, HI, USA. (tclarke@soest.hawaii.edu)

J. Dibb, C. E. Jordan, and E. Scheuer, Institute for the Study of Earth, Oceans, and Space, University of New Hampshire, Durham, NH, USA. (jack.dibb@unh.edu)

L. G. Huey, School of Earth and Atmospheric Sciences, Georgia Institute of Technology, Atlanta, GA, USA. (greg.huey@eas.gatch.edu)

H. B. Singh, NASA Ames Research Center, Moffett field, CA, USA. (hanwant.b.singh@nasa.gov)

K. L. Thornhill and E. L. Winstead, SSAI, Hampton, VA, USA. (kenneth. 1.thornhill@nasa.gov) 